\title{
Do health consultations for people with learning disabilities meet expectations? A narrative literature review
}

by Hazel M Chapman, Andrew Lovell, Ros Bramwell

\section{Accessible Summary}

People with learning disabilities have unmet health needs

Annual health checks were brought in to improve health care, but do they work?

The research shows checks lead to more tests for illness and illness being identified

A lot of people still do not see their doctor, and not all doctors do health checks

Future research needs to understand how people with disabilities feel about seeing their doctor or nurse, and how doctors and nurses feel towards them

\section{Abstract}

Aim

To explore the benefits and disadvantages of annual health checks for people with learning disabilities, including:

- What are the rationales and outcome measures for health checks?

- How well do health checks meet the needs of people with learning disabilities?

- What areas does research in this topic need to focus on in the future?

\section{Background}

Health consultations are an interpersonal activity that influence health outcomes and attitudes towards self and health professionals for people with learning disabilities. Annual health checks have been introduced to improve health inequalities for people with learning disabilities

Method

A narrative literature review of health care for people with learning disabilities was undertaken to evaluate health care for this population, and specifically the outcomes from annual health checks.

Findings 
While annual health checks have made some improvements in terms of health outcomes, attendance for appointments is still low, provision is variable and experiences of health checks for people with learning disabilities are underresearched.

\section{Conclusions}

Service-user-led research into their health experiences is needed. Research into the attitudes and experiences of health professionals in relation to people with learning disabilities is needed. Health care inequalities are only being partially addressed - improvement is needed in terms of service user experience and engagement.

\section{Background}

In the UK 2008/9 contract, NHS Employers offered payments to GP practices that took part in voluntary direct enhanced service (DES) for people with learning disabilities (NHS Employers, 2009). This included development of a register, provision of annual health checks to include: a review of physical and mental health (including health promotion needs), with appropriate referrals; a medication check; and a review of co-ordination with secondary services. Time allowed for this health check was not stipulated, but an aspiration payment of $£ 50$ per person identified on the register would be awarded, and a further $£ 50$ paid at the end of the financial year if the person had received a health check. Consequently, to avoid a "claw- back" of the funding, practices needed to see half of the patients on their register. In 2012/13, 52\% of people with learning disabilities who were eligible for an annual health check received one (Glover \& Niggebrugge, 2013). This increased to 63\% in 2014-15, although with the inclusion of 14-17 year-olds in the scheme, the uptake across the whole group remained at $52 \%$ (Hatton, 2016). It is estimated that those registered for health checks make up only $23 \%$ of the target population (Hatton, 2016)

In order to evaluate the conditions under which regular consultations can promote health and wellbeing or become an additional burden in terms of labelling (Gates, 2003), marginalisation and decreased self-efficacy and selfesteem, the experience of health consultations for the service user is key. It is not sufficient to collect large amounts of health outcome data. These data, although important in identifying differences between populations and analysing changes in outcome over time, cannot explain how supposedly beneficent health care professionals and organisations can be seen as unhelpful by service users and their families (Ali et al., 2013).

This paper analyses literature on health services for people with learning disabilities, using research into the efficacy of health consultations, to identify what constitutes an effective health consultation and how that can be evaluated in relation to the needs of people with learning disabilities. It questions whether current research captures important factors in effectiveness of healthcare consultations, particularly from the perspective of service users and their families. 


\section{Identification of Literature}

A traditional narrative literature review into health care and patient satisfaction for people with learning disabilities was carried out (Cronin, Ryan, \& Coughlan, 2008 ) with the aim of exploring the benefits and disadvantages of annual health checks for people with learning disabilities. The review aimed to answer the following:

- What are the rationales and outcome measures for health checks?

- How well do health checks meet the needs of people with learning disabilities?

- What areas does research in this topic need to focus on in the future?

The search centred on material related to adults with learning disabilities. Searches focused on literature related to health consultations, annual health checks and health outcomes for people with learning disabilities. Literature searches were carried out between 2005 and April 2017 using CINAHL, Psyclnfo, PubMed and SocIndex databases. The dates encompassed a period of growing interest in this area due to changes in health services. Limiters used included:

Adult only (18 and above)

Previous 10 years from year of search

(- Peer-reviewed journal articles

Reference lists identified other relevant literature. Terms used included major headings:

Mental retardation (used at the time in American databases) OR

Learning disability / -ies OR

Intellectual disability / -ies OR

Mental handicap

in conjunction with:

Health

Patient satisfaction

\section{Inclusion criteria:}

- Empirical research

- Related to health care

- Adults with learning disabilities

\section{Exclusion criteria:}

- Children

- Not about people with learning disabilities 
- Not related to healthcare

- Not empirical research

Overall, 27 primary research papers were found on health / healthcare and learning disabilities, 15 qualitative and 12 quantitative or mixed methods (see Table 1)

\section{Practice Context}

\subsection{Difference in health outcomes for people with learning disabilities: health care deficits and recommendations}

People with learning disabilities have poorer health outcomes and higher mortality rates (Emerson, Baines, Allerton, \& Welch, 2012) than the general population (Lindsey, 2002; Local Government Ombudsman \& Parliamentary and Health Service Ombudsman, 2009), partly due to inequitable health care. Increased health surveillance partially meets the need for General Practitioners (GPs) to make reasonable adjustments to improve health care for people with learning disabilities (Emerson \& Baines, 2011; Improving Health and Lives: Learning Disabilities Observatory, Royal College of General Practitioners, \& Royal College of Psychiatrists, 2012; Mencap, 2004; Michael \& Richardson, 2008).

The Disability Rights Commission (2006) found that differences in health needs were compounded by unresponsive health services carrying out insufficient assessments. Service users with either learning disabilities or mental health issues had reduced access to healthcare, were less likely to be referred for specialist care, and had higher morbidity and mortality. Primary care provision was regarded as less than satisfactory by about $50 \%$ of service users, or their carers, while providers thought it was satisfactory (Disability Rights Commission, 2006). Death by Indifference (Mencap, 2007) called for: an end to unequal treatment; increased knowledge of the communication and health needs of people with learning disabilities; inclusion of family members in decision-making; greater understanding of mental capacity among health professionals; an end to inappropriate judgements of best interest, based on the spurious view that people with learning disabilities have a poor quality of life; and a streamlined complaints system. They renewed their call for annual health checks.

The Healthcare for All report identified that diagnostic overshadowing, discrimination, lack of training and misconceptions about people with learning disabilities led to inadequate care (Michael \& Richardson, 2008). For example, one mother, when asking a receptionist in eye department to be aware of her son's difficulty in waiting, was told that he would have to wait like everyone else; another witness talked about the battles they had to gain access to diagnostic tests that most people would take for granted, because doctors assumed that symptoms and changed behaviours were caused by having learning disabilities and did not listen to the concerns of carers. It recommended provision of annual health checks and of liaison staff to "improve the overall quality of healthcare for people with learning disabilities across the spectrum of care" (Michael \& Richardson, 2008, p 54). A meta-analysis of 
secondary care for people with learning disabilities concluded that lack of family inclusion, poor communication, and environmental factors led to poor care. It identified learning needs in adult nurses and a requirement for learning disabilities liaison nurses (Backer, Chapman, \& Mitchell, 2009).

People with learning disabilities may need specific health interventions. For example, the higher incidence of Alzheimer's disease in people with Down syndrome (Coppus et al., 2006) suggests they need annual cognitive screening (Kozma, 2008). In the UK, specialist services have addressed this only in urban settings (Jervis \& Prinsloo, 2007). Differences in health status between people with learning disabilities and that of the general population in the UK include significantly higher incidence of bowel cancer, respiratory disease and childhood psychiatric disorders (Emerson et al., 2012). More recently, the median age at death for women with a mild learning disability was 65, compared with 83 in the general population, while for men it was 71, compared with 78 in the general population (an inequality that increases with severity of learning disability). Thus, health status inequalities compared with the general population are greater for women with learning disabilities than for men with learning disabilities (Heslop et al., 2013). In a damning meta-analysis of secondary care, in addition to issues such as delayed prescribing of antiepileptic drugs, lack of help to eat, go to the toilet and move from the bed, discriminatory attitudes towards people with learning disabilities were described as "endemic" (Bradbury-Jones, Rattray, Jones, \& MacGillivray, 2013, p. 1501).

Despite improvements in health checks, discrimination was also seen as a key barrier to health care, with diagnostic overshadowing, exclusion of family, failure to flag patients as having learning disabilities and failure to make reasonable adjustments continuing to impair access (Hollins \& BMA, 2014). Communication, information-giving and inclusion in care were still highlighted as needing improvement, even after the introduction of annual health checks (Department of Health, 2013), which have become a cornerstone of making reasonable adjustments to reduce health inequalities and improve health services for people with learning disabilities. Although recently updated guidelines and standards (Royal College of General Practitioners, 2017) mean audit tools are being developed, health consultations need evaluating in terms of experience as well as tests and interventions carried out and referrals made.

\section{Theoretical Context}

\subsection{Patient satisfaction: Definition, assessment and measurement}

A health service for people with learning disabilities that is focused on individual need rather than being service-led (Department of Health, 2001) makes it necessary to establish what people's needs are, and how well health 
services meet them. Satisfaction is a product of discrepancies between patients' expectations of care and perceptions of what they receive (Pascoe, 1983). Service users can evaluate healthcare if the definition of quality is agreed (Donabedian, 1980), although little research has considered the training needs of people with learning disabilities to evaluate services (Copeland, Luckasson, \& Shauger, 2014).

Questionnaire studies of satisfaction rarely explore patient expectations and therefore what causes dissatisfaction (Williams, Coyle, \& Healy, 1998). They tend to either lack sensitivity, making it difficult for healthcare providers to know how they can make their care more satisfactory for the patient, or mask dissatisfaction through non- response (Powell, Holloway, Lee, \& Sitzia, 2004). An interview study of mental health service users found that clients could have significant personal negative experiences of healthcare but still answer a validated client satisfaction questionnaire positively (Williams et al., 1998). Questionnaires rarely capture the complexity of human interaction, although one questionnaire study of gastroenterology outpatients' experiences $(n=227)$ found the quality oftheir interaction with the health care professional in the consultation to be the most important factor in their satisfaction (Larkins, Windsor, \& Trebble, 2013). Using satisfaction questionnaires means that patients' views on care may not be fully voiced and consequently not addressed. For service users with little experience of giving feedback, it may be difficult to express critical views (Powell et al., 2004) particularly as there is no agreed approach to eliciting satisfaction with services for people with learning disabilities (Confidential Inquiry into premature deaths of people with learning disabilities, 2014).

Current quality outcome measures used by GPs include: specific audits (such as of the appointment system); the General Practice Assessment Questionnaire [GPAQ] (Cheraghi-Sohi et al., 2008); assessment of patient recall; assessment of adherence to advice and medication; variation in prescribing; referral rates; ability to detect illness; and comparison of procedure outcomes (Halstead, Bradley, Milne, Wright \& Hollins, 2000). Patient satisfaction questionnaires "often have low validity and reliability" and are "closely related to the psychological health of the patient" (Simon, Everitt, van Dorp \& Schroeder, 2010, p 84.) However, the only key indicators assessed by Clinical Commissioning Groups in the UK are the percentage of registered people with learning disabilities who receive an annual health check (around 50\% (G. Glover \& Niggebrugge, 2013)), and the reliance on specialist inpatient care (Public Health England, 2015). Evaluation of health checks forpeople with learning disabilities cannot be achieved purely through satisfaction surveys or focus groups. Other approaches are needed to understand how well care addresses underlying psychological uncertainties associated with seeking health support (Fitzpatrick, 2007). 


\subsection{Relationship between patient satisfaction and health outcomes}

Satisfaction with healthcare is important to give service users more choice and control (Darzi, 2008), but also because patient satisfaction and adherence to advice and medication are related (Farin, Gramm, \& Schmidt, 2013; Ley, 1982 ). Non-adherence increases morbidity and mortality, health service costs and costs to the economy in terms of production, and can increase the risk of drug resistant strains of disease (Arbuthnott\& Sharpe, 2009). Cognitive factors, interpersonal factors, patient involvement and participatory decision-making, patients' attitudes towards their health, cultural variations and depression are significant predictors of adherence to health promotion or interventions (Martin, 2005). When patients trust their GPs and have continuity of care, they are more satisfied with their care (Baker, Mainous, Gray, \& Love, 2003), but these factors also predict better performance by doctors (Dulewicz \& Van Den Assem, 2013). Clinical depression in the patient was the most significant determinant of poor outcome, which itself is often undiagnosed or ineffectively treated due to poor doctor- patient communication (Martin, 2005).

Patient satisfaction is important because there is a known relationship between stress and reduced immunity, which can affect wound healing, vulnerability to infection and even cancer (Kiecolt-Glaser, Marucha, Mercado, Malarkey, \& Glaser, 1995; Kiecolt-Glaser, McGuire, Robles, \& Glaser, 2002; Marketon \& Glaser, 2008). Patient satisfaction increases when doctor and patient are concordant, or have similar expectations from the consultation (Weinman, 1997). This is partially dependent on the amount of patient involvement the GP encourages within the consultation (Elwyn et al., 2005). In the care of people with HIV/AIDS, greater levels of concordance significantly related to better quality of life, greater adherence and a higher CD4 cell count (Clucas et al., 2011). A satisfactory consultation can, in itself, be therapeutic, whereas an unsatisfactory one could directly impair well-being, as well as damaging future communication.

\subsection{The Effects of Person-Centred Communication on Health Outcomes}

Doctor-focused questions, aimed at eliciting information required for diagnosis, may result in important information being missed (Levenstein, 1986). Following patients' cues could yield important information about 
symptoms or concerns, leading to testing, treatment, or an explanation of the symptoms. Without this understanding, the doctor could miss important information that might aid not only in diagnosis, but also in patient satisfaction and adherence to health interventions (Levenstein , 1986; Mead, Bower, \& Roland, 2008; Mead, Bower, Hann,, 2002). This is different to simple affective reassurance, which does not address people's needs or lead to satisfaction in primary care consultations (Pincus et al., 2013).

A study of patients' consultations with their GPs found patients had "agendas" that they did not voice, meaning they could not be addressed (Barry, Bradley, Britten, Stevenson, \& Barber, 2000). This resulted in patients leaving with prescriptions they did not want or use correctly, patients who left with anxiety, and a general mismatch between patient expectations and doctors' views of patient expectations. Barry et al. (2000) suggested that patients are inhibited from expressing their agendas fully, even physical symptoms, due to the biomedical model within which patient and doctor interact.

GPs, aware of patient satisfaction related to trust within the consultation, recognised that they did not always achieve it, even when they sought understanding of the person's psychosocial needs (Van Roy, Vanheule, \& Deveugele, 2013). Doctors felt inhibited by time constraints, as a person- centred approach generally results in a longer consultation (Gude, Vaglum, Anvik, Bærheim, \& Grimstad, 2013). However, it would be more cost-effective in terms of appropriate testing and referral (Epstein et al., 2005b). A collaborative approach to care is particularly important in comparatively disadvantaged groups within society (Fiscella, 2002). Understanding gained from the consultation and confirmation of their views is important (Andén, Andersson, \& Rudebeck, 2005). A questionnaire study found that patients could accurately assess how much their doctor respected them (Beach, Roter, Wang, Duggan, \& Cooper, 2006). In addition, patients whom doctors respected were given more information, suggesting a possible mechanism between a more satisfying consultation and a better health outcome. An online survey of 133 carers and professionals providing care for people with learning disabilities and epilepsy suggests that carers think poor consultations are due to "poor communication, the noninvolvement of the person with an intellectual disability, and a sense of being ignored" (Thompson, Linehan, Glynn, \& Kerr, 2013, p. 384) while health professionals think they are due to poor knowledge and communication by carers.

\section{Health Care Evaluation for People with Learning Disabilities}

A number of studies analysed health outcomes data as a way of evaluating health checks for people with learning disabilities. In a pair-matched randomised, controlled trial (RCT) in Queensland, Australia, health checks did 
improve diagnosis of sensory deficits and health promotion activities for people living in supported care (Lennox et al., 2007) and in the community (Lennox et al., 2010). In a prospective study in Wales, primary care and specialist consultations did not increase following the introduction of annual health checks $(n=181)$. Nonetheless, health promotion interventions increased from 1.2 to a still insufficient 2.2 a year (Felce et al., 2008), and identification of ill health increased $(n=77)$ (Baxter et al., 2006). A single-blind RCT in Scotland of service users who had health checks by practice nurses $(n=85)$ or standard care $(n=67)$ found that differences in newly detected health needs were not significant, but that more health monitoring needs were met, suggesting potential for improved long-term health (Cooper et al., 2014). However, while practice nurses often carry out annual health checks within GP practices, this could become a barrier to communication when a service user is ill and needs a GP consultation, as there has not been an opportunity to establish a trusting relationship (Chapman, 2014).

A retrospective review (Chauhan, Kontopantelis, Campbell, Jarrett, \& Lester, 2010) of computerised records for service users with learning disabilities $(n=634)$ was carried out, but only 30 out of 81 potential English GP practices took part. Incentivised checks, such as blood pressure, body mass index (BMI) and smoking status increased significantly with the introduction of DES checks, and specific checks for sensory deficits and feeding problems, were improved by DES checks (Chauhan et al., 2010). In a follow-up interview study, service users $(n=32)$ with carers identified that there were problems with communication over appointments and ease of access, particularly if wanting to see their own doctor or if they were unwell (Chauhan et al., 2012). This seemed to have been improved with the introduction of the incentivised health checks, but some service users and carers were reluctant to attend their GP practice. Interviews with health professionals $(n=40)$ suggested that some non-DES practices found the financial incentives insufficient or felt that the DES was inequitable: "I seem to remember there was quite a lot of work involved, it seemed like ...the patients were actually getting more input than non-learning disability patients. They were getting a lot of annual checks on things; it didn't seem to make much sense to me" (Chauhan et al., 2012, p 69).

In a retrospective longitudinal cohort study $(n=8692$ from 222 GP practices in DES and 918 from 48 GP practices not in DES), using data from The Health Improvement Network database to evaluate the effectiveness of the DES annual health checks across the UK (Buszewicz et al.), those in the DES had increased likelihood of haemoglobin and cholesterol checks, general health checks, sensory needs assessments, medication reviews, health plans and secondary referrals. Gastrointestinal and thyroid disorders, constipation and body mass abnormalities were more likely to be identified in the DES group. However, errors of omission were noted in coding people for learning disabilities, and a lot of data were missing which have implications for under-inclusion and reduced accuracy of findings from this and future service evaluations. The emphasis has mostly been on physical outcomes, but a screening tool for the broader bio psychosocial needs of people with learning disabilities has been validated for use within health checks (Painter, Trevithick, Hastings, Ingham, \& Roy, 2016), making it possible to evaluate broader health outcomes in the future. 
In discussions on annual health checks, which health professionals thought were effective, a barrier to effectiveness was identified as non-attendance (Chapman, 2012). Despite the vagaries of less formal service evaluation (Ball \& Shanks, 2012) there are clear, evidence-based findings to inform practice, including the combined focus group and individual interview study that identified preferences for being included in the consultation, having preparation beforehand, and being given demonstrations of any examinations (Wullink, Veldhuijzen, Lantman-de Valk, Metsemakers, \& Dinant, 2009). Service user views have often been combined with those of their carers or with other stakeholders (Bell, 2012; Gates, 2011; Perry et al., 2013). These studies have highlighted the impact of having learning disabilities on the care needs of participants, and the importance of explanation and communication to involve people in their care (Gates, 2011) as well as using a hospital passport (Bell, 2012). It was also found that sometimes carers talked too much and the service user was excluded from the consultation; although carer support was helpful, it could be a barrier to communicating over sensitive topics, such as sexual health (Perry et al., 2013).

An interview study of people with learning disabilities and epilepsy $(n=40)$ accessed only those who had regular contact with services, identifying high satisfaction with specialist services, but some concerns that explanations were directed at service users rather than carers (Mengoni et al., 2016). However, service evaluations cannot explore why people with learning disabilities, or their carers on their behalf, choose not to access health services, particularly annual health checks, although the use of pre-existing self-advocacy groups to evaluate medical consultations (Spassiani et al., 2016; Walmsley, 2011) has effectively shown that annual health checks themselves can present challenges to the person's self-esteem and ability to engage with their health care. Research with self-advocacy groups has established that preferences for end-of-life care in people with learning disabilities include being involved in care, having friends and family present, being offered activity and being made physically comfortable (Tuffrey-Wijne, Bernal, Butler, Hollins, \& Curfs, 2007). Similar findings from interviews of cancer care service users with learning disabilities $(n=6)$ and their carers $(n=12)$ highlighted the impact of empowerment versus exclusion on their ability to understand and engage in their care (Flynn, Hulbert-Williams, Hulbert-Williams, \& Bramwell, 2016). In Ireland, community nurses discussed a number of barriers to effective community palliative care for people with learning disabilities, including late referrals and lack of personal experience and knowledge (Bailey, Doody, \& Lyons, 2016).

A study that combined health outcomes in terms of referrals, investigations and interventions with evaluation interviews identified clear evidence of health needs that were addressed, which highlights the importance of annual health checks (Cassidy, Martin, Martin, \& Roy, 2002). Only 17 people with mild or moderate learning disabilities (out of 42 who attended for a second health check) agreed to be interviewed about their experience immediately afterwards, and while most were positive "one said 'not very much', one thought the doctors were trying to hurt him, one indicated 'no' (followed by laughter) and one stated 'don't worry I'm used to it'." (Cassidy et al., 2002, p 130. ) Asking people with learning disabilities about health consultations can be affected by the setting and people who ask the questions (due to the perceived hierarchy of 
power between service users and doctors (Thompson, 2007)), resulting in not reporting their concerns. Also, any discussion of their consultation needs to be considered in the context of their personal history in order to gain understanding of how they interpret their experience. Furthermore, although annual health checks are seen as the best way to reduce health inequalities, service users need to see GPs and other health professionals at other times and for different types of consultation, but out-of-hours care is not always satisfactory (Gates, 2011; Heutmekers et al., 2016).

Inclusion in care consultations affects the way people view themselves (Kelly, 2005), highlight the importance of enabling the person with learning disabilities to develop a sense of self-efficacy through involvement in decision-making processes. By interviewing people with learning disabilities about their experiences in healthcare consultations, more should be learnt about the effects on service user's self-concept. Self-concept is important for two reasons: firstly, because it affects the person's self-esteem and therefore psychological and physical well-being, but secondly, and fundamental to the quality of healthcare, because it affects the negotiation within the health consultation that culminates in a diagnosis, management plan and ultimately, health outcomes. Evaluation of health services by people with learning disabilities (Michell, 2012) and people with mental health needs (Hutchinson\& Lovell, 2013) suggests inclusion in the process performs a similar role while simultaneously making the attitudes of service providers clearer.

Recent systematic literature reviews (Robertson, Hatton, Baines, \& Emerson, 2015; Robertson, Hatton, Emerson, \& Baines, 2014; Robertson, Roberts, \& Emerson, 2010; Robertson, Roberts, Emerson, Turner, \& Greig, 2011) and a meta-analysis (Byrne, Lennox, \& Ware, 2016) have outlined the findings from studies on the efficacy of health checks. The meta-analysis found health checks to be a significantly effective intervention in terms of vision tests, blood pressure assessment and hepatitis B vaccination, but not for hearing tests, cervical screening or weight measurement. However, studies were selected on the basis of having specific measurable outcomes that are amenable to aggregation (Byrne et al., 2016), thus excluding qualitative, service-user-focused studies. The systematic literature reviews (Robertson et al., 2015; Robertson et al., 2014; Robertson et al., 2010; Robertson et al., 2011) show improved identification of health needs and increased referrals and interventions but, despite identifying that there are issues in terms of access to health checks, found little research on the acceptability of health checks to service users and on barriers to health checks (Robertson et al., 2011). Later reviews identified some concerns over acceptability and access, relating to fear of examinations and confusion with illhealth appointment, recommending further studies into efficiency and long-term health outcomes (Robertson et al., 2014). 


\section{Discussion and Conclusion}

\subsection{Discussion}

People with learning disabilities have unmet health needs, and addressing, monitoring and demonstrating improvement in healthcare all necessitate extensive record-keeping and audit procedures. This risks depersonalising someone with learning disabilities to a series of behavioural guidelines (Wullink et al, 2009) and outcome measures, which may not tell the full story of how they experience healthcare. Satisfaction with healthcare is an important aspect of evaluating care, but there are difficulties with how, if at all, this can be measured, and whether or not those methods would be appropriate for people with learning disabilities. It is necessary to identify which aspects of a consultation someone did and did not find satisfying, but people tend to globalise their attitudes towards an experience so it is either all good or all bad.

Some of the research studies that have used discussion groups or interviewed service users, often with their carers or family members, have identified issues that would not be picked up in questionnaire evaluations, such as the importance of being included in the consultation, generally with the support of a carer, but where sensitive issues are involved, it is sometimes necessary for the service user to have some privacy (Felce et al., 2008). The importance for people with learning disabilities of explanation, inclusivity and being listened to are regular themes in the qualitative literature (Ali et al., 2013; Backer et al., 2009; Bradbury-Jones et al., 2013; Gates, 2011; Hollins et al., 2014), with suggestions that people with learning disabilities experience discrimination in their care.

The realist, quantitative approach to evaluation of health services for people with learning disabilities (Baxter et al., 2006; Cooper et al., 2014; Felce et al., 2008; Glover, Emerson \& Evison,, 2012; Lennox et al., 2010) has provided clear evidence to support the continuation and expansion of annual health checks. Nonetheless, it does not uncover the human motivations and interactions that underlie all the health encounters experienced by people with learning disabilities. Interpretivist research may involve smaller numbers and be seen differently from different perspectives, but it captures the world from the perspective of the person with learning disabilities, making it easier for the health professionals and policy makers who read it to empathise and understand their needs. Any use that health professionals can make of new knowledge in this area has to involve understanding that can bring about attitudinal change in order for it to improve the service user experience. Mechanistic models that reduce our understanding to simplistic relationships between narrowly and poorly defined variables are not helpful to practitioners. 
People with learning disabilities have a greater need for both physical and mental health interventions than people in the general population, so they are likely to require more encounters with multiple service providers, which will have a greater impact on their lives than people who do not have learning disabilities; and service providers need to be aware of the difference in health needs in people with learning disabilities to ensure that health concerns, behavioural changes and other suggestive symptoms are followed-up in order to eliminate diagnostic overshadowing and reduce inequity in health outcomes due to ineffective health promotion and inadequate care. Health checks seem to have improved diagnosis, referral rates and the frequency of some health assessments, but there is more to be done. However, the effectiveness of health encounters rests on valuing and developing a trusting relationship with the person with learning disabilities. Patient satisfaction is important from a values-based service evaluation perspective, and for its effects on adherence and even physiological well-being. There is little research on the effects of health encounters on self-concept. More evidence is needed on how perceptions of the attitudes of the health professional towards the service user in the consultation may affect relationships in future health consultations, with consequent effects on thoughts, feelings and behaviours related to help-seeking, disclosure and engagement in healthcare. Service-user-led research, such as that by Michell (2012) is more likely to confront implicit prejudice against people with learning disabilities.

Most of the evaluation of health checks involves people who have experienced them, but as the take-up is only 51\% (Chauhan et al., 2010), it seems clear that research is needed to identify why people are not attending and what GP practices do to improve attendance. The use of pre-existing self-advocacy groups (Spassiani et al., 2016; Tuffrey-Wijne et al., 2007; Walmsley, 2011) and other service user groups (Flynn et al., 2016, Wullink et al, 2009) to explore such issues is helpful, as they are more representative and able to capture the views of people who have not attended. However, more research is needed on the reluctance of some service users and their families to engage with health services, and more interview studies are needed to identify issues that service users may feel too embarrassed to discuss in public. In addition, interviews using augmented forms of communication are needed for people who find it difficult to engage in verbal conversation (Tozer, Atkin, \& Wenham, 2014). Additionally, there is some evidence that some GPs may perceive health checks as a burden that detracts from care for other patients (Chauhan et al., 2012), and research into their views and attitudes would be useful.

Charmaz (1983) found that people with chronic illness lost valued self-images, which were not replaced with positive ones. The medicalisation of the person with learning disabilities could alter their self-concept in a similar way, although it is also possible that the experience of receiving more care within mainstream health services could positively affect their self-image. However, health checks are only some of the health consultations that people with learning disabilities experience. It is not always easy to distinguish between different types of consultation, and there are often relationships between experiences due to note-taking and communication between health professionals across different consultations. Indeed, a key aspect of health checks is to identify specific health issues and refer the person to specialist services in order to address them. Additionally, the 
service users will make connections between their various health professional encounters. Consequently, it is necessary to review and explore the experiences of all health consultations in order to understand the service user's role within them, and the effects of these interactions on the service user's self-concept and engagement with health services. Thus, more research is needed to uncover where service user and service provider share meanings of the interaction within the health consultation, and where they do not, as well as to highlight those accepted views of role and self that may be shared but not recognised, and may not be helpful to feelings of satisfaction with the consultation (Epstein et al., 2005b; Epstein, Franks, Fiscella et al., 2005a).

\section{Conclusions and Implications for Practice and Research}

This narrative literature review has highlighted some continuing inequalities in health for people with learning disabilities that have not been fully addressed by annual health checks. Although the outcomes-based research has identified areas for improvement, such as low attendance, patchy provision, low uptake of screening and the difficulty of measuring patient satisfaction, it has not always addressed their cause or their remedy. For example, there is a need for more research into differences between GP practices in terms of service user experience and outcomes from health consultations, in order to highlight and disseminate best practice, and increase awareness of the causes of poor experiences and their effects on both service user satisfaction and health and wellbeing. It has identified the fundamental need to use interpretivist approaches to understand interactions constructed by humans that have longterm implications for the health, wellbeing and self-concept of people with learning disabilities and their families. Future research should focus on the service user experience of health care encounters (and that of their family and carer) and how to improve it, as well as exploring implicit attitudes of health professionals towards people with learning disabilities. Service-user-led research would aid with this, and with evaluation of medical environments and encounters with receptionists and other support workers. For practitioners, the evidence points to the importance of developing an empathetic and trustworthy relationship with service users and their families, based on respect. This does have time implications initially, but has benefits over the long-term and should be viewed as an ethical imperative and basis for quality improvement.

\section{, References}

Ali, A., Scior, K., Ratti, V., Strydom, A., King, M., \& Hassiotis, A. (2013).

Discrimination and Other Barriers to Accessing Health Care: Perspectives 
of Patients with Mild and Moderate Intellectual Disability and Their Carers. PLoS One, 8(8).

Andén, A., Andersson, S.-O., \& Rudebeck, C.-E. (2005). Satisfaction is not all-patients' perceptions of outcome of general practice consultations, a qualitative study. BMC Family Practice, 6(43).

Arbuthnott, A., \& Sharpe, D. (2009). The effect of physician-patient collaboration on patient adherence in non-psychiatric medicine. Patient Education and Counseling, 77(1), 60-67.

Backer, C., Chapman, M.,\& Mitchell, D. (2009). Access to Secondary Healthcare for People with Intellectual Disabilities: A Review of the Literature. Journal of Applied Research in Intellectual Disabilities, $22(6), 514-525$.

Bailey, M., Doody, O., \& Lyons, R. (2016). Surveying community nursing support for persons with anintellectual disability and palliative care needs. British Journal of Learning Disabilities, 44(1), 24-34.

Baker, R., Mainous, A. G., III, Gray, D. P., \& Love, M. M. (2003). Exploration of the relationship between continuity, trust in regular doctors and patient satisfaction with consultations with family doctors. Scandinavian Journal of Primary Health Care, 21(1), 27-32.

Ball, J., \& Shanks, A. (2012). Gaining feedback from people with learning disabilities. The British Journal of Occupational Therapy, 75(10), 471-477.

Barry, C., Bradley, C., Britten, N., Stevenson, F., \& Barber, N. (2000). Patients' unvoiced agendas in general practice consultations: qualitative study. British Medical Journal, 320, 1246-1250.

Baxter, H., Lowe, K., Houston, H., Jones, G., Felce, D., \& Kerr, M. (2006). Previously unidentified morbidity in patients with intellectual disability. British Journal of General Practice, 56(523), 93-98.

Beach, M. C., Roter, D. L., Wang, N.-Y., Duggan, P. S., \& Cooper, L. A. (2006). Are physicians' attitudes of respect accurately perceived by patients and associated with more positive communication behaviors? Patient Education and Counseling, 62(3), 347-354.

Bell, R. (2012). Does he have sugar in his tea? Communication between people with learning disabilities, their carers and hospital staff. Tizard Learning Disability Review, 17(2), 57-63.

Bradbury-Jones, C., Rattray, J., Jones, M., \& MacGillivray, S. (2013). Promoting the health, safety andwelfare of adults with learning disabilities in acute care settings: a structured literature review. Journal of Clinical Nursing, 22(1112), 1497-1509.

Buszewicz, M., Welch, C., Horsfall, L., Nazareth, I., Osborn, D., Hassiotis, A., . . Strydom, A. (2014). Assessment of an incentivised scheme to provide annual health checks in primary care for adults with intellectual disability: a longitudinal cohort study. The Lancet Psychiatry, 1(7), 522-530. 
Byrne, J. H., Lennox, N. G., Ware, R. S. (2016). Systematic review and metaanalysis of primary healthcare interventions on health actions in people with intellectual disability. Journal of Intellectual \& Developmental Disability, 41(1), 66-74.

Cassidy, G., Martin, D. M., Martin, G. H. B., \& Roy, A. (2002). Health Checks for People with Learning Disabilities. Journal of learning disabilities, 6(2), 123136.

Chapman, H. M. (2014). The health consultation experience for people with learning disabilities: A constructivist grounded theory study based on symbolic interactionism (Doctoral thesis), Retrieved from ChesterRep Online http://hdl.handle.net/10034/620698 : Chester, United Kingdom

Chapman, J. (2012). Annual health checks for people with learning disabilities. Learning Disability Practice, 15(1), 22-24.

Charmaz, K. (1983). Loss of self: a fundamental form of suffering in the chronically ill. Sociology of Health \& Illness, 5(2), 168-195.

Chauhan, U., Kontopantelis, E., Campbell, S., Jarrett, H., \& Lester, H. (2010). Health checks in primary care for adults with intellectual disabilities: how extensive should they be? Journal of Intellectual Disability Research, 54(6), 479-486

Chauhan, U., Reeve, J., Kontopantelis, E., Hinder, S., Nelson, P., \& Doran, T. (2012). Impact of the English Directly Enhanced Service (DES) for Learning Disability. Retrieved from Manchester, United Kingdom:

http://www.networks.nhs.uk/nhs-networks/national-health-facilitationnetwork-learning/documents/Impact\%20of\%20DES\%20-\%20Chauhan\%20Reeve-\%20Kontopantelis\%20et\%20al.pdf

Cheraghi-Sohi, S., Hole, A. R., Mead, N., McDonald, R., Whalley, D., Bower, P., \& Roland, M. (2008). What patients want from primary care consultations: a discrete choice experiment to identify patients' priorities. Annals of Family Medicine, 6(2), 107-115.

Clucas, C., Harding, R., Lampe, F. C., Anderson, J., Date, H. L., Johnson, M., Edwards, S. Fisher, Sherr, L. (2011). Doctor-patient concordance during HIV treatment switching decision-making. HIV Medicine, 12(2), 87-96.

Confidential Inquiry into premature deaths of people with learning disabilities. (2014). Learning disabilities: A definition. Retrieved from http://www.bris.ac.uk/media-library/sites/cipold/migrated/documents/ fullfinalreport.pdf

Cooper, S.-A., Morrison, J., Allan, L. M., McConnachie, A., Greenlaw, N., Melville, C. A., . . . Fenwick, E. (2014). Practice nurse health checks for adults with intellectual disabilities: a cluster-design, randomised controlled trial. The Lancet Psychiatry, 1(7), 511-521.

Copeland, S. R., Luckasson, R., \& Shauger, R. (2014). Eliciting perceptions of satisfaction with services and supports from persons with intellectual 
disability and developmental disabilities: a review of the literature. Journal of Intellectual Disability Research, 58(12), 1141-1155.

Coppus, A., Evenhuis, H., Verberne, G., Visser, F., van Gool, P., Eikelenboom, P., $\&$ van Duijin, C. (2006). Dementia and mortality in persons with Down's syndrome. Journal of Intellectual Disability Research, 50(Part 10), 768-777.

Cronin, P., Ryan, F., \& Coughlan, M. (2008). Undertaking a literature review: a step-by-step approach. British Journal of Nursing, 17(1), 38-43.

Darzi, A. (2008). High quality care for all: NHS next stage review final report. London: Department of Health, 2009.

Department of Health. (2001). Valuing People: a new strategy for learning disability for the 21st century. Stationery Office Retrieved from http://www.archive.official-documents.co.uk/document/cm50/5086/5086.p df.

Department of Health. (2013). Six Lives: Progress Report on Healthcare for People with Learning Disabilities. Retrieved from

Disability Rights Commission. (2006). Equal Treatment: Closing the Gap. A formal investigation into physical health inequalities experienced by people with learning disabilities and/or mental health problems. Retrieved from Stratford-upon-Avon, United Kingdom:

Donabedian, A. (1980). Explorations in quality assessment and monitoring.

Dulewicz, V., \& Van Den Assem, B. (2013). The GP-patient relationship and patient satisfaction. British Journal of Healthcare Management, 19(12), 596-600.

Elwyn, G., Hutchings, H., Edwards, A., Rapport, F., Wensing, M., Cheung, W.-Y., \& Grol, R. (2005). The OPTION scale: measuring the extent that clinicians involve patients in decision-making tasks. Health Expectations, 8(1), 3442.

Emerson, E., \& Baines, S. (2011). Health inequalities and people with learning disabilities in the UK. Tizard Learning Disability Review, 16(1), 42-48.

Emerson, E., Baines, S., Allerton, L., \& Welch, V. (2012). Health Inequalities \& People with Learning Disabilities in the UK: 2012 Retrieved from

Epstein, R. M., Franks, P., Shields, C. G., Meldrum, S. C., Miller, K. N., Campbell, T. L., \& Fiscella,K. (2005a). Patient-Centered Communication and Diagnostic Testing. Annals of Family Medicine, 3(5), 415-421.

Farin, E., Gramm, L., \& Schmidt, E. (2013). The patient-physician relationship in patients with chronic low back pain as a predictor of outcomes after rehabilitation. Journal of Behavioral Medicine, 36(3), 246-258.

Felce, D., Baxter, H., Lowe, K., Dunstan, F., Houston, H., Jones, G., . . Kerr, M. (2008). The impact of checking the health of adults with intellectual 
disabilities on primary care consultation rates, health promotion and contact with specialists. Journal of Applied Research in Intellectual Disabilities, $21(6)$, 597-602.

Fiscella, K. (2002). Reducing healthcare disparities through collaborative care. Families, Systems \& Health: The Journal of Collaborative Family HealthCare, 20(4), 365-373.

Fitzpatrick, R. (2007). Patient satisfaction. In S. Ayers, A. Baum, C. McManus, S. Newman, K. Wallston, J. Weinman, \& R. West (Eds.), Cambridge handbook of psychology, health and medicine (2 ed., pp. 477-482). Cambridge, United Kingdom: Cambridge University Press.

Flynn, S., Hulbert-Williams, N. J., Hulbert-Williams, L., \& Bramwell, R. (2016). 'You don't know what's wrong with you': An exploration of cancerrelated experiences in people with an intellectual disability. PsychoOncology, 25(10), 1198-1205

Gates, B. (2003). Planning for health: A contrary reflection on health action plans and health facilitators. Journal of Intellectual Disabilities, 7(1), 5-7.

Gates, B. (2011). The valued people project: users' views on learning disability nursing. British Journal of Nursing, 20(1), 15-21.

Glover, G., Emerson,E., Evison, F. (2012). IHAL2012-07 Health Checks For People With Learning Disabilities 2008-9 To 2011-12. Retrieved from http://www.improvinghealthandlives.org.uk/uploads/doc/vid_16402_IHAL20 12-07\%20Health\%20Checks\%20for\%20People\%20with\%20Learning \%20Disabilities\%202008-9\%20to\%202011-12v3.pdf

Glover, G., \& Niggebrugge, A. (2013). The Uptake of Health Checks for Adults with Learning Disabilities 2008/9 to 2012/13 Retrieved from London, United Kingdom: http://www.karentysonspage.org/20130927\%20Learning \%20Disability\%20Health\%20Checks\%20Report\%202012-3\%20final.pdf

Gude, T., Vaglum, P., Anvik, T., Bærheim, A., \& Grimstad, H. (2013). A few more minutes make a difference? The relationship between content and length of GP consultations. Scandinavian Journal of Primary Health Care, 31(1), 31-35.

Halstead, S. M., Bradley, F., Milne, S., Wright, E. C., \& Hollins, S. C. (2000). Annual Primary Health Care Contacts by People with Intellectual Disabilities: a Comparison of Three Matched Groups. Journal of Applied Research in Intellectual Disabilities, 13(2), 100-107.

Hatton C., Glover,G., Emerson, E., Brown, I. (2016) Learning Disabilities Observatory. People with learning disabilities in England 2015: Main report. London, United Kingdom, Public Health England.

Heslop, P., Blair, P., Fleming, P., Hoghton, M., Marriott, A., \& Russ, L. (2013). Confidential Inquiry into premature deaths of people with learning disabilities (CIPOLD). Bristol: Norah Fry Research Centre. 
Heutmekers, M., Naaldenberg, J., Frankena, T. K., Smits, M., Leusink, G. L., Assendelft, W. J. J., \& van Schrojenstein Lantman-de Valk, H. M. J. (2016). After-hours primary care for people with intellectual disabilities in The Netherlands-Current arrangements and challenges. Research in Developmental Disabilities, 59, 1-7.

Hollins, S. C., BMA Science and Education department, \& BMA Board of Science. (2014). Recognising the importance of physical health in mental health and intellectual disability: Achieving parity of outcomes. Retrieved from London, United Kingdom:

Hutchinson, A., \& Lovell, A. (2013). Participatory action research: moving beyond the mental health 'service user' identity. Journal of Psychiatric and Mental Health Nursing, 20(7),

Improving Health and Lives: Learning Disabilities Observatory, Royal College of General Practitioners, \& Royal College of Psychiatrists. (2012). Improving the Health and Wellbeing of People with Learning Disabilities: An Evidence-Based Commissioning Guide for Clinical Commissioning Groups (CCGs). http://www.rcgp.org.uk/revalidation-and-cpd/centre-forcommissioning/ /media/Files/CIRC/LD\%20Commissioning/RCGP\%20LD $\% 20$ Commissioning\%20Guide \%20v1\%200\%202012\%2009\%2024\%20FINAL\%20pdf.ashx.

Jervis, N., \& Prinsloo, L. (2007). How we developed a multidisciplinary screening project for people with Down's syndrome given the increased prevalence of early onset dementia. British Journal of Learning Disabilities, 36(1), 1321

Kelly, B. (2005). 'Chocolate... makes you autism': impairment, disability and childhood identities. Disability \& Society, 20(3), 261-275.

Kiecolt-Glaser, J. K., Marucha, P. T., Mercado, A. M., Malarkey, W. B., \& Glaser, R. (1995). Slowing of wound healing by psychological stress. The Lancet, 346(8984), 1194-1196.

Kiecolt-Glaser, J. K., McGuire, L., Robles, T. F., \& Glaser, R. (2002). Psychoneuroimmunology: Psychological influences on immune function and health. Journal of Consulting and Clinical Psychology, 70(3), 537-547.

Kozma, C. (2008). Down syndrome and dementia. Topics in Geriatric Rehabilitation, 24(1), 41-53.

Larkins, A. S., Windsor, A. V. C., \& Trebble, T. M. (2013). An evaluation of patient attitudes to the gastroenterology outpatient experience. European Journal of Gastroenterology \& Hepatology, 25(1), 44-55.

Lennox, N., Bain, C., Rey-Conde, T., Purdie, D., Bush, R., \& Pandeya, N. (2007). Effects of a comprehensive health assessment programme for Australian adults with intellectual disability: a cluster randomized trial. International Journal of Epidemiology, 36(1), 139-146. 
Lennox, N., Bain, C., Rey-Conde, T., Taylor, M., Boyle, F. M., Purdie, D. M., \& Ware, R. S. (2010). Cluster Randomized-Controlled Trial of Interventions to Improve Health for Adults with Intellectual Disability Who Live in Private Dwellings. Journal of Applied Research in Intellectual Disabilities, 23(4), 303-311.

Levenstein J H, M. E. C., McWhinney I R, Stewart M A and Brown J B. (1986). The Patient-Centred Clinical Method. 1. A Model for the Doctor-Patient Interaction in Family Medicine Family Practice, 3(1), 24-30.

Ley, P. (1982). Satisfaction, compliance and communication. British Journal of Clinical Psychology, 21(4), 241-254.

Ley, P. (1982 ). Satisfaction, compliance and communication. British Journal of Clinical Psychology, 21(4), 241-254.

Lindsey, M. (2002). Comprehensive health care services for people with learning disabilities. 8(2), 138-147.

Local Government Ombudsman, \& Parliamentary and Health Service Ombudsman. (2009). Six lives: the provision of public services to people with learning disabilities. Part one: overview and summary investigation reports. Retrieved from London, United Kingdom:

Marketon, J. I. W., \& Glaser, R. (2008). Stress hormones and immune function. Cellular Immunology, 252(1-2), 16-26.

Martin, L. R., Williams, S.L., Haskard, K.B., DiMatteo, M.R. (2005). The challenge of patient adherence. Therapeutics and Clinical Risk Management, 1(3), 189-199.

Mead, N., Bower, P., \& Roland, M. (2008). Factors associated with enablement in general practice: cross-sectional study using routinely-collected data. British Journal of General Practice, 58(550), 346-352.

Mead, N. B.; Bower, P., Hann. M. (2002). The impact of general practitioners' patient-centredness on patients' post-consultation satisfaction and enablement. Social Science \& Medicine, 55(2), 283-299.

Mencap. (2004). Treat Me Right! Better healthcare for people with a learning disability. Retrieved from London, United Kingdom:

Mencap. (2007). Death by indifference. London, Mencap.

Mengoni, S. E., Gates, B., Parkes, G., Wellsted, D., Barton, G., Ring, H., Khoo, M.E., Monji-Patel, D., Friedli, K., Zia, A., Durand, M.-A. (2016). 'Sometimes, it just stops me from doing anything': A qualitative exploration of epilepsy management in peoplewith intellectual disabilities and their carers. Epilepsy\& Behavior, 64(Part A), 133-139.

Michael, J., \& Richardson, A. (2008). Healthcare for All: The Independent Inquiry into Access to Healthcare for People with Learning Disabilities. Tizard Learning Disability Review, 13(4), 28-34. 
Michell, B. (2012). Checking Up On DES: My Life My Choice's research into annual health checks for people with learning disabilities in Oxfordshire. British Journal of Learning Disabilities, 40(2), 152-161.

NHS Employers (2009). Clinical Directed Enhanced Services (DESs) for GMS contract 2008/9. UKGov: London, United Kingdom

Painter, J., Trevithick, L., Hastings, R. P., Ingham, B., \& Roy, A. (2016). Development and validation of the learning disabilities needs assessment tool (LDNAT), a HoNOS-based needs assessment tool for use with people with intellectual disability. Journal of Intellectual Disability Research, 60(12), 1178-1188.

Pascoe, G. C. (1983). Patient satisfaction in primary health care: A literature review and analysis. Evaluation and Program Planning, 6(3-4), 185-210.

Perry, J., Felce, D., Kerr, M., Bartley, S., Tomlinson, J., Felce, J. (2014). Contact with Primary Care: The Experience of People with Intellectual Disabilities. Journal of Applied Research in Intellectual Disabilities, 27(3), 200-211.

Pincus, T., Holt, N., Vogel, S., Underwood, M., Savage, R., Walsh, D. A., \& Taylor, S. J. C. (2013). Cognitive and affective reassurance and patient outcomes in primary care: A systematic review. PAIN ${ }^{\circledR}, 154(11), 2407-2416$.

Powell, R. A., Holloway, F., Lee, J., \& Sitzia, J. (2004). Satisfaction research and the uncrowned king: challenges and future directions. Journal of Mental Health, 13(1), 11-20.

Public Health England. (2015). Guidance: Learning disabilities: applying All Our Health. London, United Kingdom: Gov.UK Retrieved from https://www.gov.uk/government/publications/learning-disability-applyingall-our-health/learning-disabilities-applying-all-our-health

Robertson, J., Hatton, C., Baines, S., \& Emerson, E. (2015). Systematic Reviews of the Health or Health care of People with Intellectual Disabilities: A Systematic Review to Identify Gaps in the Evidence Base. Journal of Applied Research in Intellectual Disabilities, 28(6), 455-523.

Robertson, J., Hatton, C., Emerson, E., \& Baines, S. (2014). The impact of health checks for people with intellectual disabilities: An updated systematic review of evidence. Research in Developmental Disabilities, 35(10), 24502462.

Robertson, J., Roberts, H.,\& Emerson, E. (2010). Health checks for people with learning disabilities: A systematic review of evidence. Retrieved from London, United Kingdom:

http://www.improvinghealthandlives.org.uk/uploads/doc/vid_7646_IHAL201 0-04HealthChecksSystemticReview.pdf

Robertson, J., Roberts, H., Emerson, E., Turner, S., \& Greig, R. (2011). The impact of health checks for people with intellectual disabilities: a systematic review of evidence. Journal of Intellectual Disability Research, 55(11), 1009-1019. 
Royal College of General Practitioners (2017) Health checks for people with learning disabilities toolkit. London, United Kingdom.

Simon, C., Everitt, H., van Dorp, F., \& Schroeder, K. (2010). Oxford handbook of general practice. Oxford, United Kingdom: Oxford University Press

Spassiani, N. A., Sawyer, A. R., Abou Chacra, M. S., Koch, K., Muñoz, Y. A., Lunsky, Y., \& Chacra, M. S. A. (2016). "Teaches people that I'm more than a disability": using nominal group technique in patient-oriented research for people with intellectual and developmental disabilities. Intellectual \& Developmental Disabilities, 54(2), 112-122.

Thompson, A. G. H. (2007). The meaning of patient involvement and participation in health care consultations: A taxonomy. Social Science \& Medicine, 64(6), 1297-1310.

Thompson, R., Linehan, C., Glynn, M., \& Kerr, M. P. (2013). A qualitative study of carers' and professionals' views on the management of people with intellectual disability and epilepsy: A neglected population. Epilepsy \& Behavior, 28(3), 379-385.

Tozer, R., Atkin, K., \& Wenham, A. (2014). 'My brother likes meeting new people, but don't ask him any direct questions': involving adults with autism plus learning disability in a qualitative research project. British Journal of Learning Disabilities, 42(4), 292-300.

Tuffrey-Wijne, I., Bernal, J., Butler, G., Hollins, S., \& Curfs, L. (2007). Using Nominal Group Technique to investigate the views of people with intellectual disabilities on end-of-life care provision. Journal of Advanced Nursing, 58(1), 80-89.

Van Roy, K., Vanheule, S.,\& Deveugele, M. (2013). What makes up good consultations? A qualitative study of GPs' discourses. BMC Family Practice, 14(1), 62-71.

Walmsley, J. (2011). An investigation into the implementation of Annual Health Checks for people with intellectual disabilities. Journal of Intellectual Disabilities, 15(3), 157-166.

Weinman, J. (1997). Doctor-patient communication. In A. Baum, Newman, S., Weinman, J., West, R.\& McManus, C. (Ed.), Cambridge handbook of psychology, health and medicine (pp. 284-287). Cambridge: Cambridge University Press.

Williams, B., Coyle, J.,\& Healy, D. (1998). The meaning of patient satisfaction: An explanation of high reported levels. Social Science \& Medicine, 47(9), 1351-1359.

Wullink, M., Veldhuijzen, W., Lantman-de Valk, H. M., Metsemakers, J. F., \& Dinant, G. J. (2009). Doctor-patient communication with people with intellectual disability--a qualitative study. BMC Family Practice, 10(82), 1471-2296. 



\section{\& Tables}

Table 1: Analysis of literature search papers $(n=27)$

\begin{tabular}{|c|c|c|c|c|}
\hline $\begin{array}{l}\text { Author, date of } \\
\text { publication, } \\
\text { study location }\end{array}$ & Aims of the study & Methods / study design & Findings and recommendations. & Comments \\
\hline \multicolumn{5}{|c|}{ Learning Disabilities Health Research - Qualitative studies (15 papers) } \\
\hline $\begin{array}{l}\text { Ali, A., Scior, } \\
\text { K., Ratti, V., } \\
\text { Strydom, A., } \\
\text { King, M., \& } \\
\text { Hassiotis, A. } \\
\text { (2013). } \\
\text { England, UK }\end{array}$ & $\begin{array}{l}\text { "to examine the } \\
\text { extent to which } \\
\text { adults with mild or } \\
\text { moderate } \\
\text { intellectual } \\
\text { disability } \\
\text { (described in this } \\
\text { study as } \\
\text { "patients") and } \\
\text { carers believe that } \\
\text { their needs are } \\
\text { being } \\
\text { accommodated by } \\
\text { health services" }\end{array}$ & $\begin{array}{l}\text { Interviews with patient / } \\
\text { carer dyads ( } n=14 \\
\text { dyads, plus } 1 \text { carer) - } \\
\text { thematic analysis; } \\
\text { essentialist analysis }\end{array}$ & $\begin{array}{l}\text { Findings: Perceived } \\
\text { discrimination, both direct and } \\
\text { indirect, including diagnostic } \\
\text { overshadowing. Barriers to } \\
\text { access: not communicating with } \\
\text { service user or modifying } \\
\text { communication; lack of } \\
\text { information about services; poor } \\
\text { transition to adult services; } \\
\text { insufficient referral to specialist } \\
\text { services; insufficient provision of } \\
\text { translators; insufficient } \\
\text { involvement of patients in health } \\
\text { care. } \\
\text { Recommendations: Extra support } \\
\text { needed for carers; support } \\
\text { needed for ethnic minority and } \\
\text { non-English-speaking families; } \\
\text { improve referral pathways to } \\
\text { specialist services; improve the } \\
\text { uptake of health checks; make } \\
\text { more reasonable adjustments; } \\
\text { ensure health staff training on } \\
\text { learning disabilities issues } \\
\end{array}$ & $\begin{array}{l}\text { Rich data; numbers } \\
\text { good for qualitative } \\
\text { study theme } \\
\text { agreement measured } \\
\text { between analysts; } \\
\text { findings supported by } \\
\text { quotations }\end{array}$ \\
\hline Ball, J., Shanks, & "to explore how & 70 returned & Questionnaire Findings: 90\% & Exploratory study \\
\hline
\end{tabular}




\begin{tabular}{|c|c|c|c|c|}
\hline A. (2012). UK & $\begin{array}{l}\text { members of the } \\
\text { College of } \\
\text { Occupational } \\
\text { Therapists } \\
\text { Specialist Section } \\
\text { People with } \\
\text { Learning } \\
\text { Disabilities } \\
\text { gathered feedback } \\
\text { from their service } \\
\text { users" }\end{array}$ & $\begin{array}{l}\text { questionnaires and } 12 \\
\text { follow-up telephone } \\
\text { interviews with } \\
\text { occupational therapists }\end{array}$ & $\begin{array}{l}\text { used informal discussion for } \\
\text { feedback; } 43 \% \text { documented non- } \\
\text { verbal responses; } 32 \% \text { carried } \\
\text { out interviews; } 10 \% \text { used talking } \\
\text { mats; } 14 \% \text { used visual analogue } \\
\text { scales; } 13 \% \text { used photos; } 11 \% \\
\text { used cue cards. Only } 55 \% \text { took } \\
\text { measures to reduce bias, and } \\
\text { while } 98 \% \text { used the feedback, } \\
\text { mostly it was to reflect on their } \\
\text { practice } \\
\text { Interview findings: feedback is a } \\
\text { key aspect of care, but there is } \\
\text { no systematic way of collecting } \\
\text { or recording it, so data are lost. } \\
\text { More time and resources needed } \\
\text { to collect feedback, but some } \\
\text { reluctance to hear negative } \\
\text { feedback on own service. } \\
\text { Recommendations: Feedback } \\
\text { systems needed }\end{array}$ & $\begin{array}{l}\text { using only views of } \\
\text { practitioners }\end{array}$ \\
\hline $\begin{array}{l}\text { Bell, R. (2012). } \\
\text { England }\end{array}$ & $\begin{array}{l}\text { Evaluation of a } \\
\text { “Hospital Passport } \\
\text { tool designed to } \\
\text { provide } \\
\text { information and } \\
\text { improve } \\
\text { communication } \\
\text { between people } \\
\text { with learning } \\
\text { disabilities and } \\
\text { hospital staff." }\end{array}$ & $\begin{array}{l}\text { Participatory qualitative } \\
\text { action research using } \\
\text { semi-structured } \\
\text { interviews with } 12 \\
\text { family carers and health } \\
\text { and social care staff; a } \\
\text { focus group for } 8 \text { adults } \\
\text { with } \\
\text { learning disabilities; and } \\
\text { a reflexive journal } \\
\text { analysis. Purposive } \\
\text { sampling used }\end{array}$ & $\begin{array}{l}\text { Findings: Only } 1 \text { service user } \\
\text { experienced "hospital traffic light } \\
\text { system", but consensus on } \\
\text { experiencing poor } \\
\text { communication and sense of } \\
\text { helplessness. Tool useful to } \\
\text { nurses, but only if read. } \\
\text { Recommendations: useful tool to } \\
\text { be adopted across a number of } \\
\text { patients to communicate about } \\
\text { individual needs; augmented } \\
\text { communication skills should be } \\
\text { taught to all staff; use of the tool } \\
\text { should be standard practice }\end{array}$ & $\begin{array}{l}\text { Many participants did } \\
\text { not have direct } \\
\text { experience of the tool } \\
\text { being evaluated; } \\
\text { conclusions mainly } \\
\text { based on views of } \\
\text { nurses }\end{array}$ \\
\hline
\end{tabular}




\begin{tabular}{|c|c|c|c|c|}
\hline $\begin{array}{l}\text { Flynn, S., } \\
\text { Hulbert- } \\
\text { Williams, N., } \\
\text { Hulbert- } \\
\text { Williams, L., } \\
\text { Bramwell, R. } \\
\text { (2016). North } \\
\text { Wales }\end{array}$ & $\begin{array}{l}\text { To explore cancer- } \\
\text { related } \\
\text { experiences in } \\
\text { people with } \\
\text { intellectual } \\
\text { disabilities }\end{array}$ & $\begin{array}{l}\text { Semi-structured } \\
\text { interviews with } 6 \text { people } \\
\text { who have learning } \\
\text { disabilities and cancer, } \\
\text { and sometimes their } \\
\text { carers and/or health } \\
\text { professionals, using a } \\
\text { Straussian grounded } \\
\text { theory approach to }\end{array}$ & $\begin{array}{l}\text { Findings: } \\
\text { Lack of awareness of learning } \\
\text { disabilities sometimes inhibited } \\
\text { health professional } \\
\text { communication with patient; } \\
\text { person-centred care reduced } \\
\text { distress, but poor } \\
\text { communication, such as speaking } \\
\text { in Welsh at the end of the bed, } \\
\text { made the person feel excluded } \\
\text { and distressed; caregivers were } \\
\text { sometimes involved in } \\
\text { communicating about cancer and } \\
\text { care, but they were sometimes } \\
\text { uncomfortable and deflected } \\
\text { conversations with the person, } \\
\text { inhibiting their participation in } \\
\text { their own care; this led to } \\
\text { disengagement and avoidant } \\
\text { coping }\end{array}$ & $\begin{array}{l}\text { Small dataset with } \\
\text { short interviews, so } \\
\text { model lacks rigour }\end{array}$ \\
\hline $\begin{array}{l}\text { Gates, B. } \\
\text { (2011). } \\
\text { England }\end{array}$ & $\begin{array}{l}\text { To identify the } \\
\text { needs of people } \\
\text { with learning } \\
\text { disabilities and } \\
\text { their parents in } \\
\text { relation to future } \\
\text { workforce planning } \\
\text { for health services }\end{array}$ & $\begin{array}{l}\text { Qualitative thematic } \\
\text { content analysis of } \\
\text { several focus groups } \\
\text { held separately with } \\
\text { parents of people with } \\
\text { learning disabilities } \\
(\mathrm{N}=16) \text { and people with } \\
\text { learning disabilities } \\
(\mathrm{N}=23)\end{array}$ & $\begin{array}{l}\text { People with learning disabilities } \\
\text { findings: The right kind of person } \\
\text { - carers need "police checks", } \\
\text { nursing knowledge, good } \\
\text { listening skills and personality - } \\
\text { caring and understanding; } \\
\text { Healthcare staff - hospital and } \\
\text { GP staff, including nurses and } \\
\text { doctors need more training in the } \\
\text { needs of people with learning } \\
\text { disabilities; there should be a } \\
\text { recognised person to liaise } \\
\text { between person, carers and staff; } \\
\text { Some things worry us - needles, } \\
\text { examinations, discussion about }\end{array}$ & $\begin{array}{l}\text { Explores participant } \\
\text { views as well as } \\
\text { parents/ and carers' } \\
\text { views, and the picture } \\
\text { is largely negative, } \\
\text { but points to the } \\
\text { importance of learning } \\
\text { disabilities trained } \\
\text { nurses and doctors, as } \\
\text { well as learning } \\
\text { disabilities training for } \\
\text { all healthcare staff. } \\
\text { Numbers and } \\
\text { number / structure of } \\
\text { focus groups suggest }\end{array}$ \\
\hline
\end{tabular}




\begin{tabular}{|c|c|c|c|c|}
\hline & & & $\begin{array}{l}\text { medication, ambulances, } \\
\text { emergency departments and } \\
\text { hospital stays are all frightening } \\
\text { and confusing (they are often } \\
\text { talked about rather than to) - } \\
\text { there needs to be extra support } \\
\text { for people with learning } \\
\text { disabilities; Specialist NHS staff - } \\
\text { more NHS with learning } \\
\text { disabilities training were needed, } \\
\text { particularly specialising in sexual } \\
\text { health, challenging behaviour } \\
\text { and carrying out invasive tests; } \\
\text { Making things better - separate } \\
\text { waiting places in A\&E; easy-read } \\
\text { information; use plain English; } \\
\text { have learning disability liaison } \\
\text { nurses; be included in discussion. } \\
\text { Parents / carers findings: lack of } \\
\text { service support; more learning } \\
\text { disabilities nurses needed; more } \\
\text { learning disabilities training } \\
\text { needed for healthcare staff; poor } \\
\text { communication between } \\
\text { professionals leads to care } \\
\text { deficits; examples given of } \\
\text { inadequate health care related to } \\
\text { lack of knowledge or care by } \\
\text { health professionals; good care } \\
\text { was often provided by learning } \\
\text { disabilities nurses and they } \\
\text { should be planned for in the } \\
\text { future workforce }\end{array}$ & $\begin{array}{l}\text { sufficient data to } \\
\text { support findings. } \\
\text { Themes well- } \\
\text { supported by data. }\end{array}$ \\
\hline $\begin{array}{l}\text { Heutmekers, } \\
\text { M., }\end{array}$ & $\begin{array}{l}\text { Exploratory study } \\
\text { of the organisation }\end{array}$ & $\begin{array}{l}\text { Telephone survey of } \\
\mathrm{OOH} \text { providers of }\end{array}$ & $\begin{array}{l}\text { Significant problematic areas } \\
\text { included: access to and contact }\end{array}$ & $\begin{array}{l}\text { System quite different } \\
\text { to UK, do not use }\end{array}$ \\
\hline
\end{tabular}




\begin{tabular}{|c|c|c|c|c|}
\hline $\begin{array}{l}\text { Naaldenberg, } \\
\text { J.' } \\
\text { Frankena, TK., } \\
\text { Smits, M., } \\
\text { Leusink, GL., } \\
\text { Assendelft, } \\
\text { WJJ., van } \\
\text { Schrojenstein } \\
\text { Lantman- de } \\
\text { Valk, HMJ. } \\
\text { (2016). The } \\
\text { Netherlands }\end{array}$ & $\begin{array}{l}\text { and experience of } \\
\text { out-of-hours }(\mathrm{OOH}) \\
\text { care for people } \\
\text { with learning } \\
\text { disabilities }\end{array}$ & $\begin{array}{l}\text { primary care for people } \\
\text { with learning disabilities } \\
(n=68) \text { to ask how their } \\
\text { services are organised } \\
\text { and about the expertise } \\
\text { and response times }\end{array}$ & $\begin{array}{l}\text { with generic OOH services; } \\
\text { triage; and the competence of } \\
\text { daily care delivery and of } \\
\text { intellectual disability (ID) } \\
\text { specialist doctors. Qualitatively, } \\
\text { more ID specialists were needed } \\
\text { and closer collaboration with } \\
\text { carers }\end{array}$ & mainstream services \\
\hline $\begin{array}{l}\text { Jervis and } \\
\text { Prinsloo } \\
\text { (2008). } \\
\text { Manchester, } \\
\text { UK }\end{array}$ & $\begin{array}{l}\text { Evaluation study of } \\
\text { new initiative to } \\
\text { assess dementia in } \\
\text { people with } \\
\text { dementia }\end{array}$ & $\begin{array}{l}\text { Evaluation of new } \\
\text { protocol and } \\
\text { assessment tools and } \\
\text { approaches }\end{array}$ & $\begin{array}{l}\text { In-depth qualitative and } \\
\text { quantitative assessment requires } \\
\text { time and resources. Baseline and } \\
\text { follow-up assessments needed. } \\
32 \text { out of } 135 \text { people with Down } \\
\text { Syndrome (over } 25 \text { years old) } \\
\text { were identified as having } \\
\text { dementia }\end{array}$ & $\begin{array}{l}\text { Practice evaluation } \\
\text { only }\end{array}$ \\
\hline $\begin{array}{l}\text { Mengoni, S., } \\
\text { Gates, B., } \\
\text { Parkes, } \\
\text { G.,Wellsted, D., } \\
\text { Barton, G., } \\
\text { Ring, H., Khoo, } \\
\text { M. Monji-Patel, } \\
\text { D. Friedli, K., } \\
\text { Zia, A., } \\
\text { Durand, M. } \\
\text { Hertfordshire, } \\
\text { UK }\end{array}$ & $\begin{array}{l}\text { To investigate the } \\
\text { impact and } \\
\text { management of } \\
\text { epilepsy in } \\
\text { people with } \\
\text { learning } \\
\text { disabilities }\end{array}$ & $\begin{array}{l}\text { Interview }(n=16) \text { study } \\
\text { of people with learning } \\
\text { disabilities and epilepsy } \\
\text { and their carers. } \\
\text { Thematic analysis - } \\
\text { methodology not } \\
\text { identified }\end{array}$ & $\begin{array}{l}\text { Epilepsy often imposes a } \\
\text { significant burden on a person's } \\
\text { life and the carer, and many } \\
\text { people did not have adequate or } \\
\text { accessible information about } \\
\text { their epilepsy. Management was } \\
\text { not always effective, but } \\
\text { specialist clinic care was more } \\
\text { positively experienced. }\end{array}$ & $\begin{array}{l}\text { Method of data } \\
\text { analysis not given - } \\
\text { data shown suggests } \\
\text { potential for exploring } \\
\text { other themes, such as } \\
\text { felt stigma }\end{array}$ \\
\hline $\begin{array}{l}\text { Michell, } 2012 \\
\text { Oxfordshire, } \\
\text { UK }\end{array}$ & $\begin{array}{l}\text { To explore the low } \\
\text { uptake of annual } \\
\text { health checks in }\end{array}$ & $\begin{array}{l}\text { Inclusive qualitative } \\
\text { research where } 3 \\
\text { people with learning }\end{array}$ & $\begin{array}{l}\text { Not all doctors were positive } \\
\text { towards health checks and some } \\
\text { thought treating everyone the }\end{array}$ & $\begin{array}{l}\text { Person-centred } \\
\text { research shows } \\
\text { insights that could }\end{array}$ \\
\hline
\end{tabular}




\begin{tabular}{|c|c|c|c|c|}
\hline & $\begin{array}{l}\text { Oxfordshire and } \\
\text { explore attitudes } \\
\text { and knowledge } \\
\text { within GP practices } \\
\text { about the DES } \\
\text { initiative }\end{array}$ & $\begin{array}{l}\text { disabilities were } \\
\text { supported to develop } \\
\text { and ask interview } \\
\text { questions and record } \\
\text { impressions of their } \\
\text { visits to GP practices } \\
\text { offering annual health } \\
\text { checks. Combination of } \\
\text { interview, observation } \\
\text { and case study. }\end{array}$ & $\begin{array}{l}\text { same was sufficient. Education } \\
\text { was needed regarding easy-read } \\
\text { leaflets and use of the Cardiff } \\
\text { template. Some health check } \\
\text { experiences were unwelcoming } \\
\text { and were not given time for a full } \\
\text { assessment }\end{array}$ & $\begin{array}{l}\text { only be gained by } \\
\text { people with learning } \\
\text { disabilities - } \\
\text { methodology and data } \\
\text { analysis not made } \\
\text { explicit. Small } \\
\text { numbers. }\end{array}$ \\
\hline $\begin{array}{l}\text { Painter, J., } \\
\text { Trevithick, L., } \\
\text { Hastings, R. P., } \\
\text { Ingham, B., } \\
\text { Roy, A. (2016) } \\
\text { England, UK }\end{array}$ & $\begin{array}{l}\text { To develop and } \\
\text { validate a brief } \\
\text { assessment tool } \\
\text { for initial holistic } \\
\text { assessment of the } \\
\text { holistic health } \\
\text { needs of people } \\
\text { with learning } \\
\text { disabilities }\end{array}$ & $\begin{array}{l}\text { Development of } \\
\text { questionnaire based on } \\
\text { other assessment tools } \\
\text { used with people with } \\
\text { disability /illness, } \\
\text { mental health and } \\
\text { learning disabilities, as } \\
\text { well as from life issues } \\
\text { identified in literature } \\
\text { ( } n=1692 \text { ). Redundant } \\
\text { questions were } \\
\text { removed and test-rest } \\
\text { reliability checked and } \\
\text { comparisons made with } \\
\text { the outcomes from } \\
\text { other, more onerous } \\
\text { and specific assessment } \\
\text { tools, for validity. }\end{array}$ & $\begin{array}{l}\text { A broad holistic assessment tool } \\
\text { has been developed and } \\
\text { validated for use in people with } \\
\text { learning disabilities. Further } \\
\text { research is needed, but test- } \\
\text { retest results appear promising. }\end{array}$ & $\begin{array}{l}\text { Process explained in } \\
\text { sufficient detail to } \\
\text { provide transparency } \\
\text { and a rationale for } \\
\text { choices made. This } \\
\text { appears to be a useful } \\
\text { tool that can be } \\
\text { shared between all } \\
\text { services, and } \\
\text { particularly for mental } \\
\text { health needs } \\
\text { identification, but } \\
\text { needs further } \\
\text { validation studies }\end{array}$ \\
\hline $\begin{array}{l}\text { Perry, J.,Felce, } \\
\text { D., Kerr, M., } \\
\text { Bartley, S., } \\
\text { Tomlinson, J., } \\
\text { Felce, J. (2013) } \\
\text { Wales, UK }\end{array}$ & $\begin{array}{l}\text { Combination of } \\
\text { two studies to } \\
\text { explore the } \\
\text { experience of } \\
\text { people with } \\
\text { intellectual } \\
\text { disabilities when }\end{array}$ & $\begin{array}{l}\text { Focus group study (5-15 } \\
\text { per group, } n=102 \text {, of } \\
\text { whom } 39 \text { had received } \\
\text { annual health } \\
\text { checks). Study } 1(n=63) \\
\text { discussion topics: } \\
\text { 'Getting to see the }\end{array}$ & $\begin{array}{l}\text { Barriers to appointments } \\
\text { included complex telephone } \\
\text { menus and long waits - } \\
\text { preference for seeing a } \\
\text { professional known to them. } \\
\text { Accessing out-of-hours services } \\
\text { was sometimes a lengthy process }\end{array}$ & $\begin{array}{l}\text { Large service user } \\
\text { study, providing } \\
\text { opportunity for broad } \\
\text { evaluation of health } \\
\text { consultation } \\
\text { experience and } \\
\text { therefore an important }\end{array}$ \\
\hline
\end{tabular}




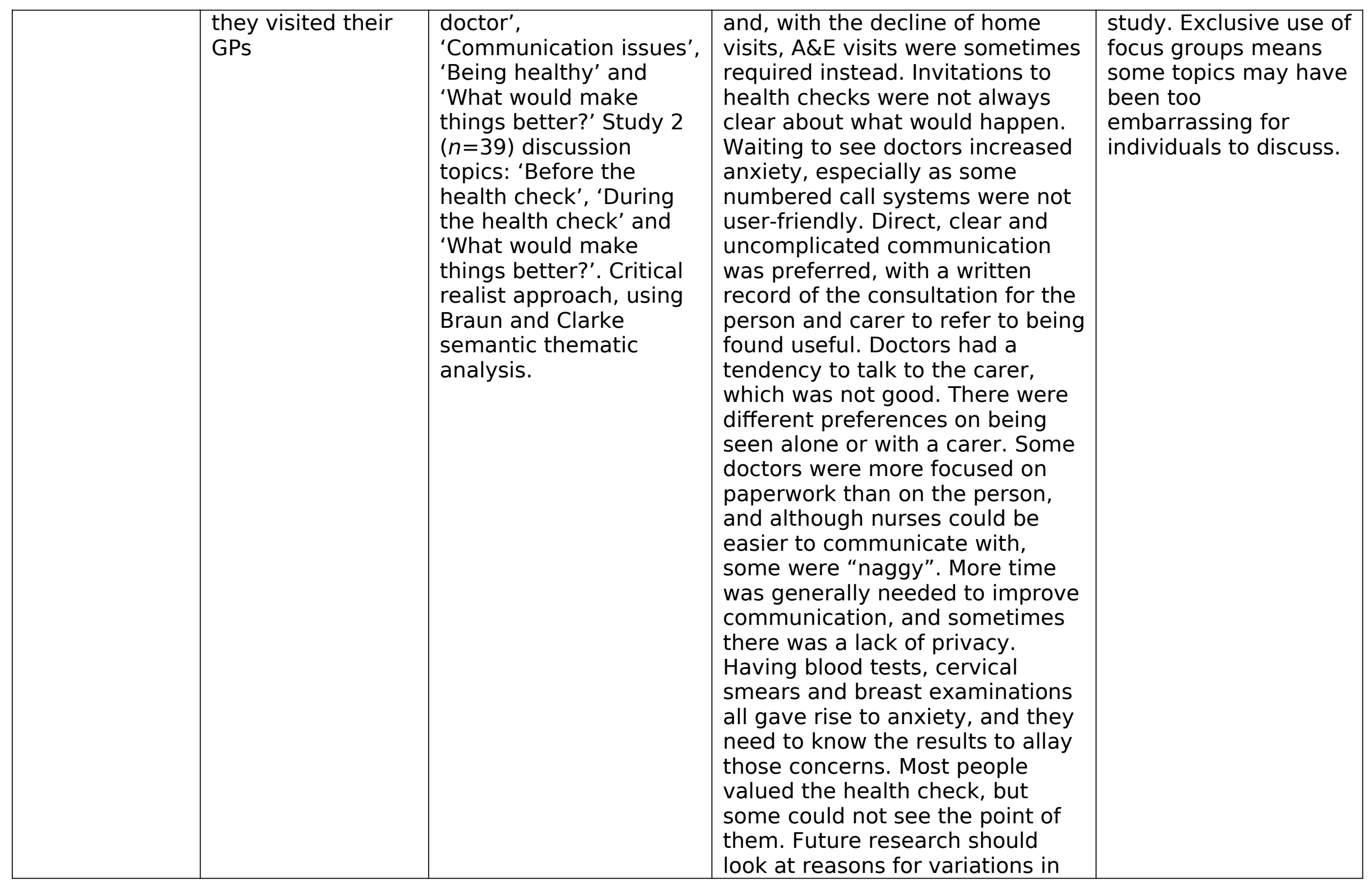




\begin{tabular}{|c|c|c|c|c|}
\hline & & & $\begin{array}{l}\text { satisfaction, including variations } \\
\text { in service user and GP } \\
\text { characteristics. }\end{array}$ & \\
\hline $\begin{array}{l}\text { Spassiani, N. } \\
\text { A., Sawyer, A. } \\
\text { R., Abou } \\
\text { Chacra, M. S., } \\
\text { Koch, K., } \\
\text { Muñoz, Y. A., } \\
\text { Lunsky, Y., \& } \\
\text { Chacra, M. S. } \\
\text { A. (2016). } \\
\text { Toronto, } \\
\text { Canada }\end{array}$ & $\begin{array}{l}\text { To discuss } \\
\text { experiences of } \\
\text { medical } \\
\text { consultations }\end{array}$ & $\begin{array}{l}\text { Service users ( } n=10) \\
\text { invited from self- } \\
\text { advocacy groups, to } \\
\text { attend meeting where } \\
\text { nominal group } \\
\text { technique (NGT) was } \\
\text { used. Points raised by } \\
\text { individuals were } \\
\text { separately voted on to } \\
\text { produce their "top } \\
\text { three" likes and dislikes } \\
\text { on seeing a doctor, and } \\
\text { then related to different } \\
\text { healthcare tools. Field } \\
\text { notes of the discussion } \\
\text { were taken. Grounded } \\
\text { Theory (Corbin and } \\
\text { Strauss) thematic } \\
\text { analysis carried out on } \\
\text { qualitative data. }\end{array}$ & $\begin{array}{l}\text { Getting checked to make sure } \\
\text { everything is OK was most } \\
\text { popular, although knowing or } \\
\text { seeing the same doctor was also } \\
\text { liked. Long waiting times to see } \\
\text { the doctor were the most disliked } \\
\text { factor. The service users were } \\
\text { able to identify specific aspects } \\
\text { about the poster, video and } \\
\text { health communication booklet } \\
\text { that they like and disliked, } \\
\text { showing the ability to give usable } \\
\text { feedback using this approach. }\end{array}$ & $\begin{array}{l}\text { NGT a new method for } \\
\text { people with learning } \\
\text { disabiliteis - shares } \\
\text { some common themes } \\
\text { around health } \\
\text { consultations with UK } \\
\text { studies, but key } \\
\text { finding is the potential } \\
\text { use of NGT with } \\
\text { people with learning } \\
\text { disabilities to gain } \\
\text { specific and detailed } \\
\text { feedback on services. } \\
\text { Numbers small and } \\
\text { group research means } \\
\text { some sensitive } \\
\text { matters may not be } \\
\text { discussed. }\end{array}$ \\
\hline $\begin{array}{l}\text { Thompson, R., } \\
\text { Linehan, C., } \\
\text { Glynn, M., \& } \\
\text { Kerr, M. P. } \\
\text { (2013). UK and } \\
\text { Ireland }\end{array}$ & $\begin{array}{l}\text { To examine the } \\
\text { impact of epilepsy } \\
\text { on individuals with } \\
\text { intellectual } \\
\text { disability and their } \\
\text { caregivers, and } \\
\text { their views on the } \\
\text { adequacy and } \\
\text { quality of available } \\
\text { treatment for this } \\
\text { population. }\end{array}$ & $\begin{array}{l}\text { Bristol online survey } \\
\text { returned by }(n=92) \\
\text { professionals, paid } \\
\text { caregivers, and family } \\
\text { members who support } \\
\text { individuals with } \\
\text { intellectual disability } \\
\text { and epilepsy. Thematic } \\
\text { analysis of mainly } \\
\text { qualitative data. }\end{array}$ & $\begin{array}{l}\text { Perception by professionals } \\
\text { particularly of inequitable } \\
\text { treatment, partly due to } \\
\text { difficulties in assessing capacity, } \\
\text { obtaining informed consent and } \\
\text { not being offered treatments due } \\
\text { to disability. Family members } \\
\text { found medication management } \\
\text { difficult due to trade-offs with } \\
\text { side-effects, such as drowsiness. } \\
\text { The physical impact and social } \\
\text { stigma of epilepsy were }\end{array}$ & $\begin{array}{l}\text { Large study of an } \\
\text { under-explored } \\
\text { population that } \\
\text { identifies significant } \\
\text { areas to be addressed } \\
\text { in practice and future } \\
\text { research. The } \\
\text { anonymous nature of } \\
\text { the survey suggests } \\
\text { that people are able to } \\
\text { express their true } \\
\text { opinions, which may }\end{array}$ \\
\hline
\end{tabular}




\begin{tabular}{|c|c|c|c|c|}
\hline & & & $\begin{array}{l}\text { problematic. Professionals saw } \\
\text { high staff turnover and poor } \\
\text { record-keeping as problematic } \\
\text { when seeing people in clinic, } \\
\text { although paid carers suggested } \\
\text { professionals sometimes needed } \\
\text { to communicate with the service } \\
\text { user and use simpler language, } \\
\text { with more time for consultations } \\
\text { to allow for this. Specialist } \\
\text { services were highly valued, but } \\
\text { not available to all. Learning } \\
\text { disability community or liaison } \\
\text { nurses were helpful in co- } \\
\text { ordinating care and providing } \\
\text { support. Many parents had } \\
\text { experienced diagnostic } \\
\text { overshadowing with their } \\
\text { children before the correct } \\
\text { diagnosis of epilepsy was given. } \\
\text { Administration of appropriate } \\
\text { "rescue" drugs important - } \\
\text { buccal midazolam rated highly } \\
\text { compared with previous regime } \\
\text { of rectal diazepam, but there are } \\
\text { training and permissions issues. } \\
\text { Overall, side-effects are an } \\
\text { underrated problem, and } \\
\text { specialist nurses are needed to } \\
\text { support this group of service } \\
\text { users and their families / carers. }\end{array}$ & $\begin{array}{l}\text { be difficult when } \\
\text { people are highly } \\
\text { dependent on } \\
\text { services. Findings } \\
\text { well-supported by } \\
\text { quotations from data. } \\
\text { Themes and findings } \\
\text { confirmed by two } \\
\text { researchers. }\end{array}$ \\
\hline $\begin{array}{l}\text { Tuffrey-Wijne, } \\
\text { I., Bernal, J., } \\
\text { Butler, G., } \\
\text { Hollins, S., \& } \\
\end{array}$ & $\begin{array}{l}\text { To investigate the } \\
\text { use of Nominal } \\
\text { Group Technique } \\
\text { as a method to }\end{array}$ & $\begin{array}{l}\text { Scenario-based use of } \\
\text { nominal group } \\
\text { technique (NGT) }(n=14) \\
\text { to identify preferred }\end{array}$ & $\begin{array}{l}\text { Top four preferences: } \\
\text { Involvement in one's own care } \\
\text { Presence of family and friends } \\
\text { Offering activities to the ill }\end{array}$ & $\begin{array}{l}\text { Small-scale study } \\
\text { demonstrating use of } \\
\text { this technique in detail } \\
\text { and suggesting how } \\
\end{array}$ \\
\hline
\end{tabular}




\begin{tabular}{|c|c|c|c|c|}
\hline $\begin{array}{l}\text { Curfs, L. } \\
\text { (2007). } \\
\text { London, UK }\end{array}$ & $\begin{array}{l}\text { elicit the views of } \\
\text { people with } \\
\text { intellectual } \\
\text { disabilities on } \\
\text { sensitive issues, } \\
\text { here end-of-life } \\
\text { care provision. }\end{array}$ & $\begin{array}{l}\text { care for someone with a } \\
\text { life-limiting illness and } \\
\text { learning disabilities. }\end{array}$ & $\begin{array}{l}\text { person } \\
\text { Physical comfort measures. } \\
\text { Use of pictures helpful in } \\
\text { reducing emotional distress, and } \\
\text { might be useful in eliciting } \\
\text { preferences from people with } \\
\text { learning disabilities and a life- } \\
\text { limiting illness. The discussion of } \\
\text { ideas was found to be helpful by } \\
\text { participants in helping them to } \\
\text { reflect on their own attitudes. }\end{array}$ & $\begin{array}{l}\text { use of pictures might } \\
\text { also aid in individual } \\
\text { decision processes for } \\
\text { people with learning } \\
\text { disabilities. Identified } \\
\text { potential themes for } \\
\text { future research in this } \\
\text { area. }\end{array}$ \\
\hline $\begin{array}{l}\text { Walmsley, J. } \\
\text { (2011). } \\
\text { Oxfordshire, } \\
\text { UK }\end{array}$ & $\begin{array}{l}\text { An investigation } \\
\text { into the } \\
\text { implementation of } \\
\text { annual health } \\
\text { checks (AHCs). }\end{array}$ & $\begin{array}{l}\text { Inclusive research study } \\
\text { of local GP practices } \\
\text { offering AHCs, but GP } \\
\text { interviews (?n=6) } \\
\text { carried out by author. } \\
\text { Service user health } \\
\text { champion plus support } \\
\text { worker wrote reports on } \\
\text { their experience of the } \\
\text { GP practices ( } n=3) \text {, and } \\
\text { on his own AHC. 30 } \\
\text { service users were } \\
\text { supported to give } \\
\text { feedback on the AHC } \\
\text { using a questionnaire- } \\
\text { based focus group } \\
\text { discussion. }\end{array}$ & $\begin{array}{l}\text { GPs: Difficulty in identifying those } \\
\text { eligible for AHCs; uncertainty } \\
\text { over its benefits; new diagnoses } \\
\text { made; familiarises people with } \\
\text { learning disabilities and their } \\
\text { support services with their GP; } \\
\text { supports health promotion; } \\
\text { provides opportunity for } \\
\text { behavioural advice; heightens GP } \\
\text { awareness of needs of this } \\
\text { population; concerns over cost- } \\
\text { effectiveness of DES; limited GP } \\
\text { awareness of mental capacity } \\
\text { assessment; educational needs } \\
\text { identified re: caring for people } \\
\text { with learning disabilities. } \\
\text { Experience of visiting GP } \\
\text { practices highlighted the } \\
\text { importance of: punctuality, } \\
\text { courtesy, basic communication } \\
\text { and the attitudes of reception } \\
\text { and clinical staff } \\
\text { Focus group questionnaire } \\
\text { results: needed more information }\end{array}$ & $\begin{array}{l}\text { Despite small } \\
\text { numbers, an example } \\
\text { of how inclusive } \\
\text { research can reveal } \\
\text { aspects of the } \\
\text { experience that are } \\
\text { inaccessible through } \\
\text { other means. }\end{array}$ \\
\hline
\end{tabular}




\begin{tabular}{|c|c|c|c|c|}
\hline & & & $\begin{array}{l}\text { about the AHC, what it involved, } \\
\text { that it did not meant anything } \\
\text { was wrong, and what to do if an } \\
\text { invitation was not received. } \\
\text { The reflection on an AHC } \\
\text { suggested it did not meet the } \\
\text { required standard and that the } \\
\text { service user was treated the } \\
\text { same as other patients, rather } \\
\text { than having reasonable } \\
\text { adjustments made. }\end{array}$ & \\
\hline \multicolumn{5}{|c|}{ Learning Disabilities Health Literature (Quantitative and Mixed Methods) - 12 papers } \\
\hline $\begin{array}{l}\text { Bailey, M., Doody, } \\
\text { o., Lyons, R. } \\
\text { (2016). Ireland }\end{array}$ & $\begin{array}{l}\text { To describe the } \\
\text { provision of } \\
\text { community nursing } \\
\text { support for people } \\
\text { with learning } \\
\text { disabilities needing } \\
\text { end-of-life care }\end{array}$ & $\begin{array}{l}\text { Questionnaire } \\
\text { administered to all } \\
\text { primary care nurses } \\
\text { who might be involved } \\
\text { in this care }-32 \% \\
\text { response }(n=94) \text {. } \\
\text { Descriptive statistical } \\
\text { analysis of quantitative } \\
\text { data; Burnard thematic } \\
\text { analysis of qualitative } \\
\text { data. Paradigm not } \\
\text { stated. }\end{array}$ & $\begin{array}{l}\text { Quantitative findings: } \\
\text { Only one RNLD; } 35 \% \text { experienced } \\
\text { caring for SU with learning } \\
\text { disabilities and end-of-life needs } \\
\text { in past } 3 \text { years; } 33 \text { nurses had } \\
\text { received } 85 \text { referrals; } 61 \% \text { lived } \\
\text { with family, } 23 \% \text { in group homes, } \\
\text { others in learning disability } \\
\text { services, alone or in nursing } \\
\text { home; } 72 \% \text { remained at home } \\
\text { until death } \\
\text { Qualitative findings: } \\
\text { Need for specific education for } \\
\text { working with people with learning } \\
\text { disabilities and their families } \\
\text { identified; communication skills, } \\
\text { including sign language and } \\
\text { communicating with families, } \\
\text { were identified as needing } \\
\text { development; a need for greater } \\
\text { resources, both technology aids, } \\
\text { specialist services, more time for }\end{array}$ & $\begin{array}{l}\text { Questionnaire content } \\
\text { validity based on } \\
\text { previous research } \\
\text { recommendations. } \\
\text { Qualitative analysis } \\
\text { carried out } \\
\text { independently by } 2 \\
\text { researchers and } \\
\text { agreed upon. } \\
\text { Descriptive study that } \\
\text { may not transfer to UK } \\
\text { experience. Focused } \\
\text { on nursing needs. }\end{array}$ \\
\hline
\end{tabular}




\begin{tabular}{|c|c|c|c|c|}
\hline & & & $\begin{array}{l}\text { advance planning and more time } \\
\text { for care interventions were } \\
\text { identified. }\end{array}$ & \\
\hline $\begin{array}{l}\text { Baxter, H., } \\
\text { Lowe, K., } \\
\text { Houston, H., } \\
\text { Jones, G., } \\
\text { Felce, D., } \\
\text { Kerr, M. } \\
\text { (2006). Wales, } \\
\text { UK }\end{array}$ & $\begin{array}{l}\text { To predict the } \\
\text { likelihood that } \\
\text { health checks } \\
\text { would newly } \\
\text { identify morbidity }\end{array}$ & $\begin{array}{l}\text { Analysis of health data } \\
\text { following health checks } \\
(n=141) \text { in } 40 \mathrm{GP} \\
\text { practices }\end{array}$ & $\begin{array}{l}51 \% \text { had new needs recognised, } \\
\text { of whom } 63 \% \text { had } 1 \text { health need, } \\
25 \% 2 \text { health needs, and } 12 \% \\
\text { more than } 2.16(9 \%) \text { had serious } \\
\text { new morbidity discovered }\end{array}$ & $\begin{array}{l}\text { This adds support to a } \\
\text { number of studies } \\
\text { suggesting that heath } \\
\text { checks identify } \\
\text { morbidity that affects } \\
\text { quality of life and } \\
\text { health outcomes. }\end{array}$ \\
\hline $\begin{array}{l}\text { Buszewicz et } \\
\text { al. (2014) }\end{array}$ & $\begin{array}{l}\text { Retrospective } \\
\text { longitudinal } \\
\text { logistical } \\
\text { regression to } \\
\text { compare } \\
\text { differences in } \\
\text { characteristics } \\
\text { between } \\
\text { incentivised v } \\
\text { non-incentivised } \\
\text { practices' cohorts } \\
\text { of patients with } \\
\text { learning }\end{array}$ & $\begin{array}{l}\text { Longitudinal cohort } \\
\text { study using data from } \\
\text { The Health } \\
\text { Improvement Network } \\
\text { primary care } \\
\text { database. Multivariate } \\
\text { logistic regression to } \\
\text { assess associations } \\
\text { between various } \\
\text { characteristics and } \\
\text { whether } \\
\text { or not practices had } \\
\text { opted in to the } \\
\text { incentivised scheme. } \\
\text { Used data for } 8692 \\
\text { patients from } 222 \text { DES } \\
\text { practices and those for } \\
918 \text { patients in } 48 \text { non- } \\
\text { DES practices. }\end{array}$ & $\begin{array}{l}\text { Findings: Significant positive } \\
\text { differences in uptake of blood } \\
\text { tests (apart from HbA); general } \\
\text { health status, offering of health } \\
\text { check (although this was still } \\
\text { below } 30 \% \text { in the incentivised } \\
\text { group in } 2009-11 \text { ), and number } \\
\text { of specific health assessments } \\
\text { carried out. However, only some } \\
\text { diseases had significantly higher } \\
\text { rates of new diagnosis, including } \\
\text { thyroid and gastrointestinal } \\
\text { disorder, constipation and } \\
\text { obesity. } 40 \% \text { of people with } \\
\text { specific syndromes such as Down } \\
\text { syndrome were not coded as } \\
\text { having general learning } \\
\text { disabilities and were therefore } \\
\text { not automatically offered an } \\
\text { annual health check. } \\
\text { Recommendations: As, despite } \\
\text { missing data, health checks } \\
\text { appear to improve health } \\
\text { surveillance and health }\end{array}$ & $\begin{array}{l}\text { 1. Cohorts allocated } \\
\text { by inference - no } \\
\text { coding for DES } \\
\text { incentivised } \\
\text { practice } \\
\text { 2. A lot of missing } \\
\text { data, making } \\
\text { observation of } \\
\text { health care and } \\
\text { health outcomes } \\
\text { for people with } \\
\text { learning disabilities } \\
\text { difficult and } \\
\text { inexact }\end{array}$ \\
\hline
\end{tabular}




\begin{tabular}{|c|c|c|c|c|}
\hline & & & $\begin{array}{l}\text { outcomes, they should be } \\
\text { adopted universally to reduce } \\
\text { inequities in health. However, the } \\
\text { differences in provision and } \\
\text { uptake of health checks needs to } \\
\text { be addressed. Future longitudinal } \\
\text { studies are needed. }\end{array}$ & \\
\hline $\begin{array}{l}\text { Cassidy, G., } \\
\text { Martin, D.M., } \\
\text { Martin, G.H.B., } \\
\text { Roy, A. (2002). } \\
\text { England, UK }\end{array}$ & $\begin{array}{l}\text { Evaluation of } \\
\text { multi-professional } \\
\text { health checks in a } \\
\text { GP practice }\end{array}$ & $\begin{array}{l}\text { Quantitative health } \\
\text { outcomes }(n=69) \text { and } \\
\text { qualitative SU interview } \\
\text { evaluations }(n=17), \\
\text { carers' questionnaires } \\
(n=23)\end{array}$ & $\begin{array}{l}\text { T1 check, } 94 \% \text { had a physical } \\
\text { problem requiring intervention, } \\
71 \% \text { had a mental health } \\
\text { problem. Further problems and } \\
\text { follow-ups were found at T2 } \\
\text { check. } 4 \text { of the } 17 \text { SUs did not } \\
\text { have a positive experience. } 21 \text { of } \\
23 \text { carers thought health checks } \\
\text { a good idea, but some issues } \\
\text { identified including: appointment } \\
\text { times; waiting time; not being } \\
\text { informed of drug side-effects; } \\
\text { treatment by receptionist }\end{array}$ & $\begin{array}{l}\text { SUs and carers with } \\
\text { negative feelings / } \\
\text { experiences may not } \\
\text { have wanted to take } \\
\text { part in questionnaires } \\
\text { and interviews. } \\
\text { Children included in } \\
\text { study - outcomes not } \\
\text { differentiated between } \\
\text { identified groups, e.g., } \\
\text { children, adults } \\
\text { previously living in } \\
\text { institutions. Not clear } \\
\text { which diagnoses were } \\
\text { new. Study carried out } \\
\text { by people responsible } \\
\text { for intervention and in } \\
\text { GP practice, so people } \\
\text { may not have felt } \\
\text { comfortable in } \\
\text { expressing feelings }\end{array}$ \\
\hline $\begin{array}{l}\text { Chauhan, U., } \\
\text { Kontopantelis, E., } \\
\text { Campbell, S., } \\
\text { Jarrett, H., Lester, } \\
\text { H. (2010). } \\
\text { England, UK }\end{array}$ & $\begin{array}{l}\text { To explore the } \\
\text { additional value of } \\
\text { a health check } \\
\text { compared with } \\
\text { standard care } \\
\text { (incentivised } \\
\text { quality outcomes }\end{array}$ & $\begin{array}{l}\text { Patient records }(n=634) \\
\text { from } 27 \text { GP practices } \\
\text { were evaluated against } \\
\text { QOF and ID health } \\
\text { check domains using } \\
\text { read codes }\end{array}$ & $\begin{array}{l}\text { Only } 9 \text { practices carried out AHCS } \\
(n=92) \text {. Cervical screening in } \\
\text { relevant population higher in } \mathrm{AHC} \\
\text { group - } 86 \% \text { v } 56 \% \text {, despite } 67 \% \\
\text { of those tested having been } \\
\text { previously exception-reported. } \\
\text { Recording of blood pressure, BMI }\end{array}$ & $\begin{array}{l}\text { Data unable to explain } \\
\text { why so few practices } \\
\text { offered health checks. } \\
\text { Computerised read } \\
\text { code data problematic } \\
\text { as outcome measure - } \\
\text { QOF read codes }\end{array}$ \\
\hline
\end{tabular}




\begin{tabular}{|c|c|c|c|c|}
\hline & framework [QOF]) & & $\begin{array}{l}\text { and smoking status (QOF) were } \\
\text { well-recorded, but improved on } \\
\text { AHC. Learning disabilities-specific } \\
\text { assessments, such as feeding } \\
\text { and sensory difficulties, less well- } \\
\text { recorded, although improved } \\
\text { with AHC. }\end{array}$ & $\begin{array}{l}\text { commonly used, but } \\
\text { variation in recording } \\
\text { of other items. }\end{array}$ \\
\hline $\begin{array}{l}\text { Cooper, S-A., } \\
\text { Morrison, J. Allan, } \\
\text { L.M., } \\
\text { McConnachie, A., } \\
\text { Greenlaw, N., } \\
\text { Melville, C.A., } \\
\text { Baltzer, M.C., } \\
\text { McArthur, L.A., } \\
\text { Lammie, C. Martin, } \\
\text { G,. Grieve, E.A.D., } \\
\text { Fenwick, E. } \\
\text { (2014). Scotland, } \\
\text { UK }\end{array}$ & $\begin{array}{l}\text { To assess whether } \\
\text { practice nurse- } \\
\text { delivered health } \\
\text { checks could } \\
\text { improve the health } \\
\text { of adults with } \\
\text { learning } \\
\text { disabilities } \\
\text { compared with } \\
\text { standard care }\end{array}$ & $\begin{array}{l}\text { A cluster-design, single- } \\
\text { blind, randomised } \\
\text { controlled trial } \\
\text { (reviewers masked, but } \\
\text { not participants and } \\
\text { nurses) - IV = standard } \\
\text { care ( } \mathrm{n}=85 \text { ) or standard } \\
\text { care plus health check } \\
\text { ( } n=67) ; \mathrm{DV}=\text { health } \\
\text { outcomes, measured by } \\
\text { incidence of new health } \\
\text { needs assessed and } \\
\text { met; number of health } \\
\text { monitoring and } \\
\text { promotion needs met; } \\
\text { EQ-5D and SF-36 } \\
\text { scores; serious adverse } \\
\text { events; change in } \\
\text { resource use or costs } \\
\text { over } 9 \text { months from } \\
\text { randomisation. This } \\
\text { involved both data } \\
\text { extraction from records } \\
\text { and SU / carer } \\
\text { interviews }\end{array}$ & $\begin{array}{l}\text { EQ-5D improved for control } \\
\text { group, but not SF-36. Quality- } \\
\text { adjusted life year outcomes } \\
\text { showed the intervention group } \\
\text { care had more effective and } \\
\text { cheaper care. For people who live } \\
\text { alone, health monitoring was } \\
\text { significantly improved. }\end{array}$ & $\begin{array}{l}\text { Study unable to } \\
\text { explore why some } \\
\text { people did not attend } \\
\text { for health checks or } \\
\text { why some practices } \\
\text { did not offer them. } \\
\text { Single-blind aspect of } \\
\text { study compromised by } \\
\text { some participants } \\
\text { identifying they had } \\
\text { received health } \\
\text { checks when health } \\
\text { questionnaires being } \\
\text { administered. }\end{array}$ \\
\hline $\begin{array}{l}\text { Coppus, A., } \\
\text { Evenhuis, H., } \\
\text { Verberne, G., }\end{array}$ & $\begin{array}{l}\text { To assess the } \\
\text { prevalence of } \\
\text { dementia in people }\end{array}$ & $\begin{array}{l}\text { 4-year longitudinal } \\
\text { study of annual } \\
\text { dementia assessments }\end{array}$ & $\begin{array}{l}16.8 \%(n=85) \text { had dementia at } \\
\text { baseline. Up to age } 49 \\
\text { prevalence } 8.9 \% \text {; age } 50-54 \text {, }\end{array}$ & $\begin{array}{l}\text { A large study with } \\
\text { rigorous diagnostic } \\
\text { procedures }\end{array}$ \\
\hline
\end{tabular}




\begin{tabular}{|c|c|c|c|c|}
\hline $\begin{array}{l}\text { Visser, F., van } \\
\text { Gool, P., } \\
\text { Eikelenboom, P., } \\
\text { van Duijin, C. } \\
\text { (2006). The } \\
\text { Netherlands }\end{array}$ & $\begin{array}{l}\text { with Down } \\
\text { syndrome }\end{array}$ & $\begin{array}{l}\text { in people with Down } \\
\text { syndrome ( } n=506) \text {. } \\
\text { Comprehensive history } \\
\text { and examination of } \\
\text { intellectual functioning } \\
\text { and physical health } \\
\text { taken along with a } \\
\text { dementia scale for } \\
\text { people with learning } \\
\text { disabilities (DMR) }\end{array}$ & $\begin{array}{l}17.7 \% \text {; age } 55-59,32.1 \% \text {; over } \\
60, \text { no further increase in the } \\
\text { prevalence of dementia } 25.6 \%\end{array}$ & \\
\hline $\begin{array}{l}\text { Felce, D., Baxter, } \\
\text { H., Lowe, K., } \\
\text { Dunstan, F., } \\
\text { Houston, H., Jones, } \\
\text { G., Grey, J., Felce, } \\
\text { J., } \\
\text { Kerr, M. (2008). } \\
\text { Wales, UK }\end{array}$ & $\begin{array}{l}\text { To evaluate } \\
\text { whether } \\
\text { health checking } \\
\text { stimulated } \\
\text { increased } \\
\text { consultation with } \\
\text { the general } \\
\text { practitioner or } \\
\text { another member } \\
\text { of the primary care } \\
\text { team, increased } \\
\text { health promotion } \\
\text { actions } \\
\text { undertaken } \\
\text { outside the health } \\
\text { check or increased } \\
\text { contact } \\
\text { with specialists. }\end{array}$ & $\begin{array}{l}\text { Medical record data } \\
\text { extraction ( } n=77) \text { of } \\
\text { categorical data: GP } \\
\text { practice consultations; } \\
\text { health promotion } \\
\text { activity; contact with } \\
\text { specialists, comparing } 8 \\
\text { x pre-consultation 6- } \\
\text { month time periods } \\
\text { with } 7 \text { x post- } \\
\text { consultation 6-month } \\
\text { time periods. Non- } \\
\text { parametric analysis } \\
\text { used to compare means } \\
\text { between groups }\end{array}$ & $\begin{array}{l}\text { No significant difference in } \\
\text { frequency of consultations pre- } \\
\text { and post-health check, or in } \\
\text { contact with specialists. Health } \\
\text { promotion actions increased } \\
\text { significantly after } 1^{\text {st }} \text { health check }\end{array}$ & $\begin{array}{l}\text { Large attrition rate to } \\
\text { follow-up, partly due } \\
\text { to withdrawal of } 1 / 3 \text { of } \\
\text { GP practices from } 2^{\text {nd }} \\
\text { stage of study, leaving } \\
\text { sample size small - } \\
\text { larger study needed. }\end{array}$ \\
\hline $\begin{array}{l}\text { Halstead, S.M., } \\
\text { Bradley, F., Milne, } \\
\text { S. Wright, E.C., } \\
\text { Hollins, S.C. } \\
(2000) \text {. England, } \\
\text { UK }\end{array}$ & $\begin{array}{l}\text { To compare } \\
\text { patterns of } \\
\text { provision of annual } \\
\text { primary care } \\
\text { consultations } \\
\text { during transition } \\
\text { from hospital to }\end{array}$ & $\begin{array}{l}\text { Three groups (Grp 1), } \\
\text { Trust hospital doctor } \\
\text { (Grp 2), primary care } \\
\text { GP (Grp 3) [prior to } \\
\text { hospital closure] } \\
\text { matched on age, } \\
\text { gender, dependency }\end{array}$ & $\begin{array}{l}\text { Significantly lower rate of } \\
\text { consultations in Group } 3 \\
\text { compared with Groups } 1 \text { and } 2 \text {. }\end{array}$ & $\begin{array}{l}\text { Suggests frequency of } \\
\text { primary care } \\
\text { consultations for } \\
\text { people with learning } \\
\text { disabilities may be } \\
\text { insufficient for their } \\
\text { needs. }\end{array}$ \\
\hline
\end{tabular}




\begin{tabular}{|c|c|c|c|c|c|}
\hline & community care & \multicolumn{2}{|c|}{$\begin{array}{l}\text { ( } n=110) \text { non-parametric } \\
\text { comparison of numbers } \\
\text { of consultations }\end{array}$} & & \\
\hline $\begin{array}{l}\text { Lennox, N., Bain, } \\
\text { C., Rey-Conde, T., } \\
\text { Purdie, D., Bush, } \\
\text { R., Pandeya, N. } \\
\text { (2007). } \\
\text { Queensland, } \\
\text { Australia }\end{array}$ & $\begin{array}{l}\text { To measure } \\
\text { effectiveness of } \\
\text { comprehensive } \\
\text { health assessment } \\
\text { programme } \\
\text { (CHAP) (based on } \\
\text { Cardiff health } \\
\text { check) in } \\
\text { enhancing health } \\
\text { promotion, disease } \\
\text { prevention and } \\
\text { case-finding } \\
\text { activities, and } \\
\text { appropriate } \\
\text { interventions in } \\
\text { primary health } \\
\text { care }\end{array}$ & \multicolumn{2}{|c|}{$\begin{array}{l}\text { Cluster randomised } \\
\text { control trial with pair- } \\
\text { matched participants } \\
\text { ( } n=430 \text { in } 34 \text { clusters at } \\
\text { 1-year follow-up) to } \\
\text { measure differences in } \\
\text { health promotion, } \\
\text { disease prevention and } \\
\text { case-finding activities, } \\
\text { and appropriate } \\
\text { interventions using case } \\
\text { record data extraction } \\
\text { over one year }\end{array}$} & $\begin{array}{l}\text { Significant increase in most } \\
\text { health promotion and disease } \\
\text { prevention interventions, } \\
\text { particularly in relation to sensory } \\
\text { loss and immunisation. } \\
\text { Differences in case-finding and } \\
\text { interventions were not } \\
\text { significant. . GP evaluations } \\
\text { suggested they found the } \\
\text { assessment useful in enhancing } \\
\text { health outcomes }\end{array}$ & $\begin{array}{l}\text { Data extraction } \\
\text { method may not have } \\
\text { captured all the new } \\
\text { diagnoses and } \\
\text { interventions } \\
\text { accurately }\end{array}$ \\
\hline \multirow[t]{2}{*}{$\begin{array}{l}\text { Lennox, N., Bain, } \\
\text { C., Rey-Conde, T., } \\
\text { Taylor, M., Boyle, } \\
\text { F.M., Purdie, D.M., } \\
\text { Ware, R.S. } \\
\text { (2010). } \\
\text { Queensland, } \\
\text { Australia }\end{array}$} & \multirow[t]{2}{*}{$\begin{array}{l}\text { To evaluate } \\
\text { whether two } \\
\text { health assessment } \\
\text { tools improved } \\
\text { healthcare for a } \\
\text { community } \\
\text { population of } \\
\text { adults with } \\
\text { intellectual } \\
\text { disability: the Ask } \\
\text { health diary and } \\
\text { the CHAP tool. }\end{array}$} & \multicolumn{2}{|c|}{$\begin{array}{l}\text { A cluster randomised } \\
\text { control trial }(n=242) \\
\text { with } 2 \times 2 \text { factorial } \\
\text { design, comparing } \\
\text { clinical activity in the } 12 \\
\text { months preceding and } \\
\text { following intervention } \\
\text { date, using case record } \\
\text { data extraction. }\end{array}$} & $\begin{array}{l}\text { Significant increases in sensory } \\
\text { assessments and immunisations } \\
\text { for CHAP participants (in any } \\
\text { combination). No significant } \\
\text { improvements with Ask health } \\
\text { diary in any combination. }\end{array}$ & \multirow[t]{2}{*}{$\begin{array}{l}\text { Potential under- } \\
\text { reporting of new } \\
\text { diagnoses / } \\
\text { interventions in } \\
\text { medical records of } \\
\text { CHAP participants due } \\
\text { to recording in CHAP } \\
\text { documents - may } \\
\text { contribute to lack of } \\
\text { recorded significant } \\
\text { improvement in this } \\
\text { area. }\end{array}$} \\
\hline & & Ask & CHAP and & & \\
\hline
\end{tabular}




\begin{tabular}{|c|c|c|c|c|c|}
\hline & & $\begin{array}{l}\text { health } \\
\text { diary } \\
(n=51)\end{array}$ & Ask (70) & & \\
\hline $\begin{array}{l}\text { Wullink, M., } \\
\text { Veldhuijzen, } \\
\text { W., Lantman- } \\
\text { de Valk, H. M., } \\
\text { Metsemakers, } \\
\text { J. F., \& Dinant, } \\
\text { G. J. (2009). } \\
\text { S.E. } \\
\text { Netherlands }\end{array}$ & $\begin{array}{l}\text { Comparison of } \\
\text { communication } \\
\text { preferences of } \\
\text { people with ID and } \\
\text { the professional } \\
\text { criteria used to } \\
\text { assess doctor- } \\
\text { patient } \\
\text { communication by } \\
\text { GPs? }\end{array}$ & \multicolumn{2}{|c|}{$\begin{array}{l}1 \text { naturally-occurring } \\
\text { focus group }(n=10) \text { and } \\
2 \text { interviews - content } \\
\text { analysis of data and } \\
\text { guidelines on GP } \\
\text { communication to } \\
\text { compare with service } \\
\text { user (SU) preferences to } \\
\text { produce similarity and } \\
\text { difference percentage } \\
\text { scores }\end{array}$} & $\begin{array}{l}\text { Manuals focused on behaviours, } \\
\text { while SUs also identified } \\
\text { attitudes. Differences between } \\
\text { guidelines and SU preferences } \\
\text { were: more time should be } \\
\text { allowed for the consultation } \\
\text { (usual } 10 \text { minutes); the doctor } \\
\text { should ask permission of SU } \\
\text { before talking to the support } \\
\text { worker. }\end{array}$ & $\begin{array}{l}\text { Small numbers; } \\
\text { attitudinal preferences } \\
\text { not explored because } \\
\text { they could not be } \\
\text { compared with } \\
\text { behavioural guidance; } \\
\text { comparison with } \\
\text { normal consultation } \\
\text { times, but underline } \\
\text { importance of longer } \\
\text { consultation times. }\end{array}$ \\
\hline
\end{tabular}

